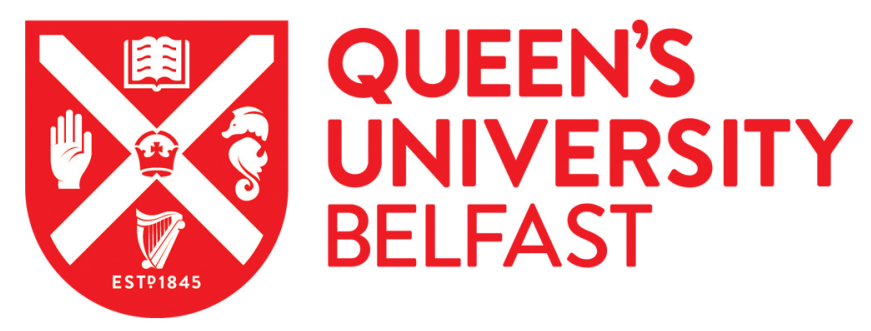

\title{
Evaluation of an in situ spatial resolution instrument for fixed beds through the assessment of the invasiveness of probes and a comparison with a micro-kinetic model
}

Touitou, J., Aiouache, F., Burch, R., Douglas, R., Hardacre, C., Morgan, K., Sa, J., Stewart, C., Stewart, J., \& Goguet, A. (2014). Evaluation of an in situ spatial resolution instrument for fixed beds through the assessment of the invasiveness of probes and a comparison with a micro-kinetic model. Journal of Catalysis, 319, 239-246. https://doi.org/10.1016/j.jcat.2014.09.006

Published in:

Journal of Catalysis

Document Version:

Early version, also known as pre-print

Queen's University Belfast - Research Portal:

Link to publication record in Queen's University Belfast Research Portal

Publisher rights

Copyright (C) 2014 Elsevier Inc. All rights reserved.

This is a pre-print of an article published in final version at doi: 10.1016/j.jcat.2014.09.006

\section{General rights}

Copyright for the publications made accessible via the Queen's University Belfast Research Portal is retained by the author(s) and / or other copyright owners and it is a condition of accessing these publications that users recognise and abide by the legal requirements associated with these rights.

Take down policy

The Research Portal is Queen's institutional repository that provides access to Queen's research output. Every effort has been made to ensure that content in the Research Portal does not infringe any person's rights, or applicable UK laws. If you discover content in the

Research Portal that you believe breaches copyright or violates any law, please contact openaccess@qub.ac.uk. 


\section{Evaluation of an in situ spatial resolution instrument for fixed beds through the assessment of the invasiveness of probes and a comparison with a micro kinetic model.}

Jamal Touitou ${ }^{\mathrm{a}}$, Farid Aiouache ${ }^{\mathrm{b}}$, Robbie Burch ${ }^{\mathrm{a}}$, Roy Douglas ${ }^{\mathrm{c}}$, Christopher Hardacre ${ }^{\mathrm{a}}$,

Kevin Morgan ${ }^{\mathrm{a}}$, Jacinto Sád ${ }^{\mathrm{d}}$, Caomhán Stewart ${ }^{\mathrm{a}}$, Jonathan Stewart ${ }^{\mathrm{c}}$, Alexandre Goguet ${ }^{\mathrm{a}, *}$.

${ }^{a}$ School of Chemistry and Chemical Engineering, Queen's University, Belfast, BT9 5AG, UK

${ }^{\mathrm{b}}$ Engineering Department, Lancaster University, Lancaster, LAI 4YR, UK

${ }^{\mathrm{C} S}$ Shool of Mechanical and Aerospace Engineering, Queen's University, Belfast, BT9 5AH, UK

${ }^{\mathrm{d}} \mathrm{MoHCa}$, Institute of Physical Chemistry of the Polish Academy of Sciences, Warsaw, Poland

*Corresponding author: Fax: +44 (0)28 90974687; email: a.goguet@qub.ac.uk

Equations from kinetic model

The rate of reaction, $r$, is given by Eqn $(\mathrm{S} 1)$.

$$
r=\frac{k C_{p, i} C_{p, j}}{R(\theta)} \rho \text { Eqn. (S1) }
$$

where, the inhibition, $R(\theta)$, was calculated using Equation $\mathrm{S} 2$ and the rate constant, $k$, was calculated with Equation S3.

$$
\begin{gathered}
\left.R(\theta)=\left[1+k_{a 1} C_{p, C O}+k_{a 2} C_{p, C_{3} H_{6}}\right]^{2}\left[1+k_{a 3}\left[C_{p, C O} C_{p, C_{3} H_{6}}\right]^{2}\right]\left[1+k_{a 4} C_{p, N O}{ }^{0.7}\right] \text { Eqn. (S }\right) \\
k=A \exp \left(\frac{-E_{a}}{R T}\right) \text { Eqn. (S3) }
\end{gathered}
$$

The micro-kinetics side of the model uses Equations S4 to S9 to calculate the rate of reaction. Since the micro-kinetic side deals with each reaction elementary step individually, it needs to take into account the adsorption and desorption of each gas species, as well as the surface reaction. The rate constant for adsorption was given by Equation S4, as presented by Hauptmann et al. ${ }^{\text {Error! Bookmark not defined. }}$, and derived from transition state theory.

$$
k_{A}=\frac{R T}{\rho \sqrt{2 \pi M_{i} R T}}\left(\frac{T}{T_{0}}\right)^{\beta} S_{o i} \quad \text { Eqn. (S4) }
$$

The rate of reaction is given by:

$$
r_{A}=k_{A} C_{g, i} C_{C v} C_{v} \quad \text { Eqn. (S5) }
$$

The rate of desorption of the gases from the catalyst surface was given by Equation S6 with the rate constant found using the Arrhenius equation, as shown by Equation S7.

$$
\begin{array}{cr}
r_{D}=k_{D} C_{D, i} & \text { Eqn. (S6) } \\
k_{D}=A_{D} \exp \left(\frac{-E_{a}}{R T}\right) & \text { Eqn. (S7) }
\end{array}
$$


The rate of reaction on the surface between the adsorbed gas species was found using Equation S8, with the rate constant obtained from the Arrhenius equation as shown by Equation S9.

$$
\begin{array}{cr}
r_{S}=k C_{S, i} C_{S, j} C_{C v} & \text { Eqn. (S8) } \\
k_{S}=A_{S} \exp \left(\frac{-E_{a}}{R T}\right) & \text { Eqn. (S9) }
\end{array}
$$

Table S1: Intrinsic kinetic reactions ${ }^{1,2}$

\begin{tabular}{|l|c|c|c|c|}
\hline \multicolumn{2}{|c|}{ Intrinsic Reaction } & $\begin{array}{c}\text { Pre exponential/ } \\
\text { Sticking coefficient }\end{array}$ & $\begin{array}{c}\text { Activation } \\
\text { energies }\end{array}$ & $\begin{array}{c}\text { Temperature } \\
\text { exponent }\end{array}$ \\
\hline & & $\mathrm{s}^{-1} /(-)$ & $\mathrm{kJ} \mathrm{mol}^{-1}$ & $(-)$ \\
\hline 1 & $\mathrm{CO}+\mathrm{Pt}_{(\mathrm{s})}=\mathrm{CO}_{(\mathrm{s})}$ & 1.00 & - & 0.00 \\
\hline 2 & $\mathrm{CO}_{(\mathrm{s})}=\mathrm{CO}+\mathrm{Pt}_{(\mathrm{s})}$ & $5.66 \times 10^{15}$ & 166 & 0.39 \\
\hline 3 & $\mathrm{CO}_{2}+\mathrm{Pt}_{(\mathrm{s})}=\mathrm{CO}_{2(\mathrm{~s})}$ & $1.9510^{-1}$ & - & 0.25 \\
\hline 4 & $\mathrm{CO}_{2(\mathrm{~s})}=\mathrm{CO}_{2}+\mathrm{Pt}_{(\mathrm{s})}$ & $3.60 \times 10^{12}$ & 12 & 0.25 \\
\hline 5 & $\mathrm{O}_{2}+2 \mathrm{Pt}_{(\mathrm{s})}=2 \mathrm{O}_{(\mathrm{s})}$ & $5.4210^{-2}$ & - & 0.77 \\
\hline 6 & $2 \mathrm{O}_{(\mathrm{s})}=\mathrm{O}_{2}+2 \mathrm{Pt}_{(\mathrm{s})}$ & $8.41 \times 10^{12}$ & 209 & 0.93 \\
\hline & $\mathrm{Surface} \mathrm{reactions}_{2}$ & & & \\
\hline 7 & $\mathrm{CO}_{(\mathrm{s})}+\mathrm{O}_{(\mathrm{s})}=\mathrm{CO}_{2(\mathrm{~s})}$ & $2.39 \times 10^{20}$ & 103 & - \\
\hline 8 & $\mathrm{CO}_{2(\mathrm{~s})}=\mathrm{CO}_{(\mathrm{s})}+\mathrm{O}_{(\mathrm{s})}$ & $2.83 \times 10^{8}$ & 125 & - \\
\hline
\end{tabular}


Figure S1: Representation of (a) the velocity and (b) the pressure drop in the packed catalyst bed with the sampling located at $2.5 \mathrm{~mm}$.

a)

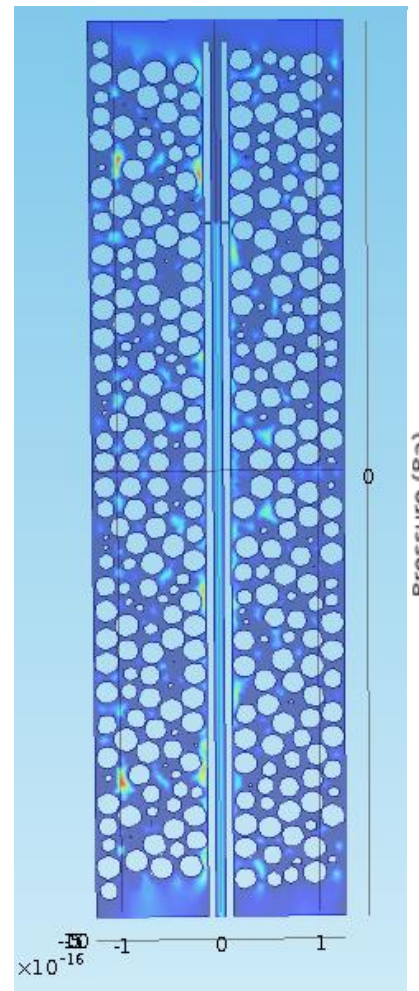

b)

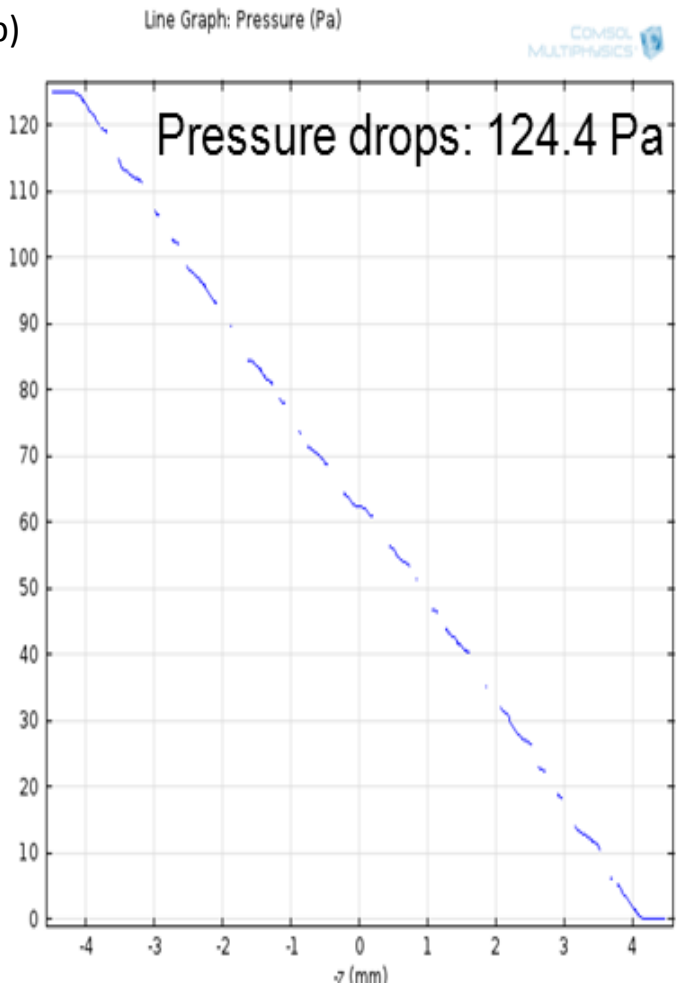


Figure S2: Representation of (a) the velocity and (b) the pressure drop in the packed catalyst bed with the sampling located at $4.5 \mathrm{~mm}$.

a)

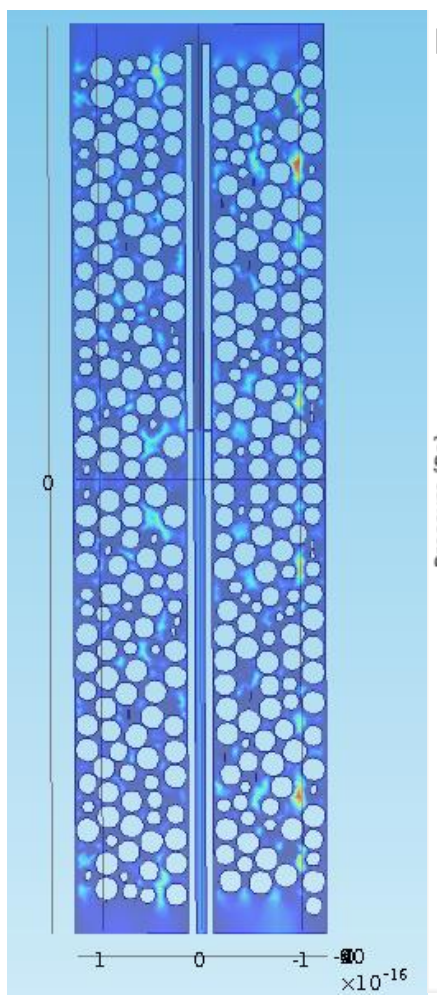

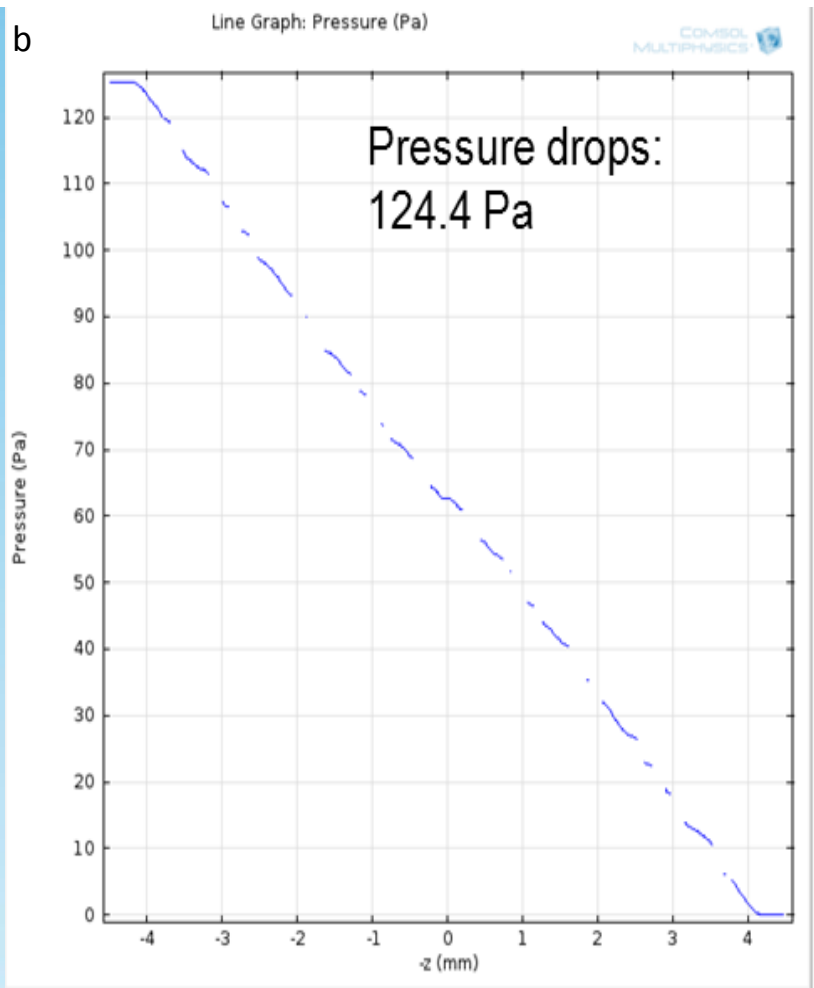


Figure S3: Representation of (a) the velocity and (b) the pressure drop in the packed catalyst bed with the sampling located at $6.5 \mathrm{~mm}$.

a

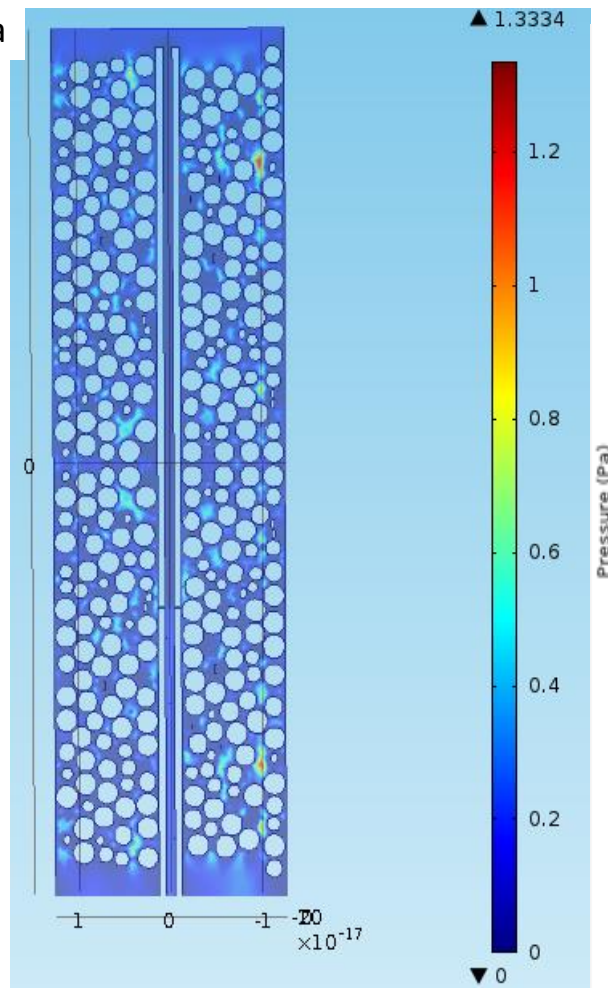

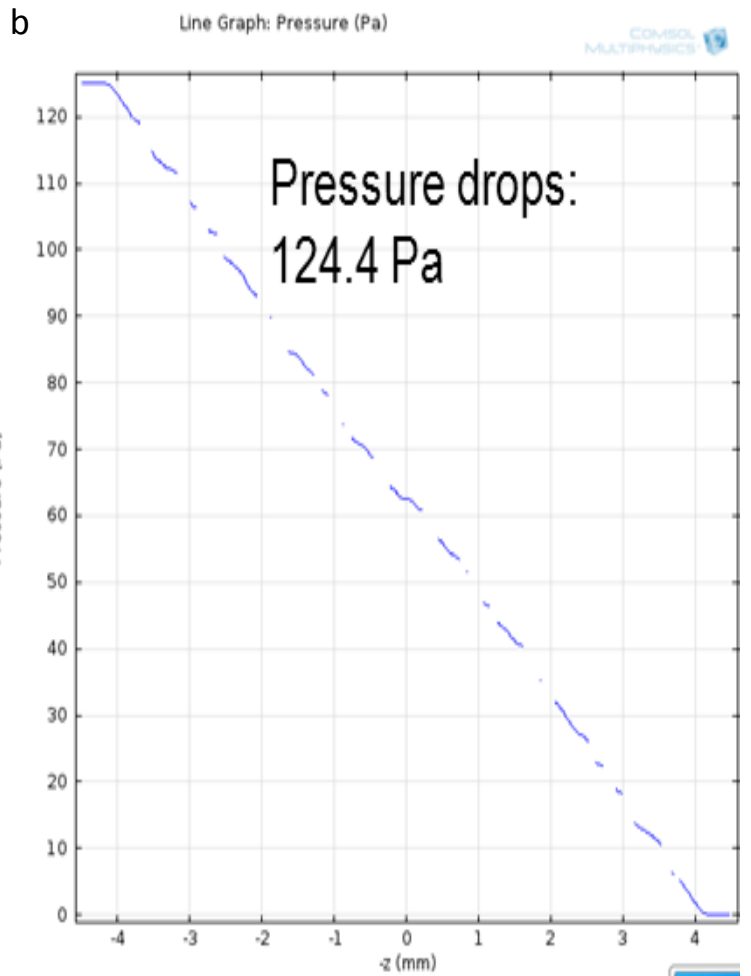


Comparison of gas concentration profiles from experimental and fully simulated model

\section{CO oxidation with $1 \% \mathrm{CO}$ at $175^{\circ} \mathrm{C}$}

Figure S4: CO experimental (square) and fully simulated model (line) evolution with $1 \%$ $\mathrm{CO}$ in the feed at $175^{\circ} \mathrm{C}$. The catalyst bed is represented by the shaded area.

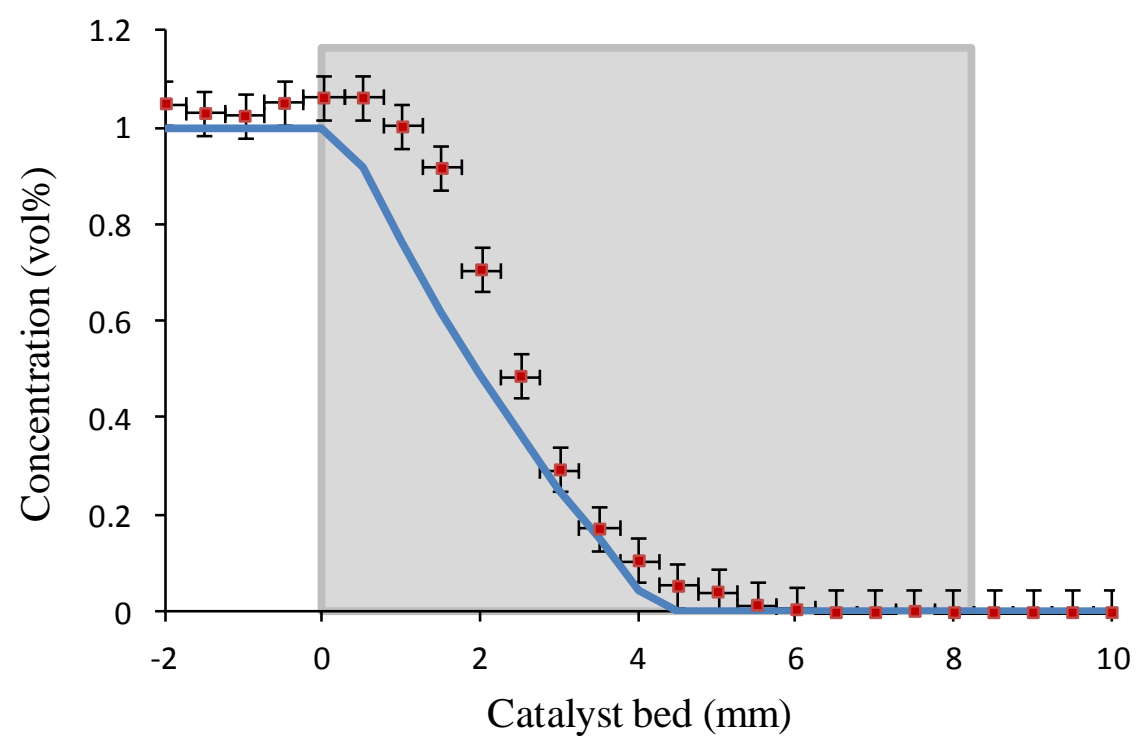

For Figure S4 the average accuracy was found to be 0.83 , giving an average error of $16.9 \%$. The $R^{2}$ value was 0.97 , meaning that the error on a point by point basis was $2.8 \%$, while the critical error was $19.2 \%$. 
Figure S5: $\mathrm{O}_{2}$ experimental (square) and fully simulated model (line) evolution with $1 \% \mathrm{CO}$ in the feed at $175^{\circ} \mathrm{C}$. The catalyst bed is represented by the shaded area.

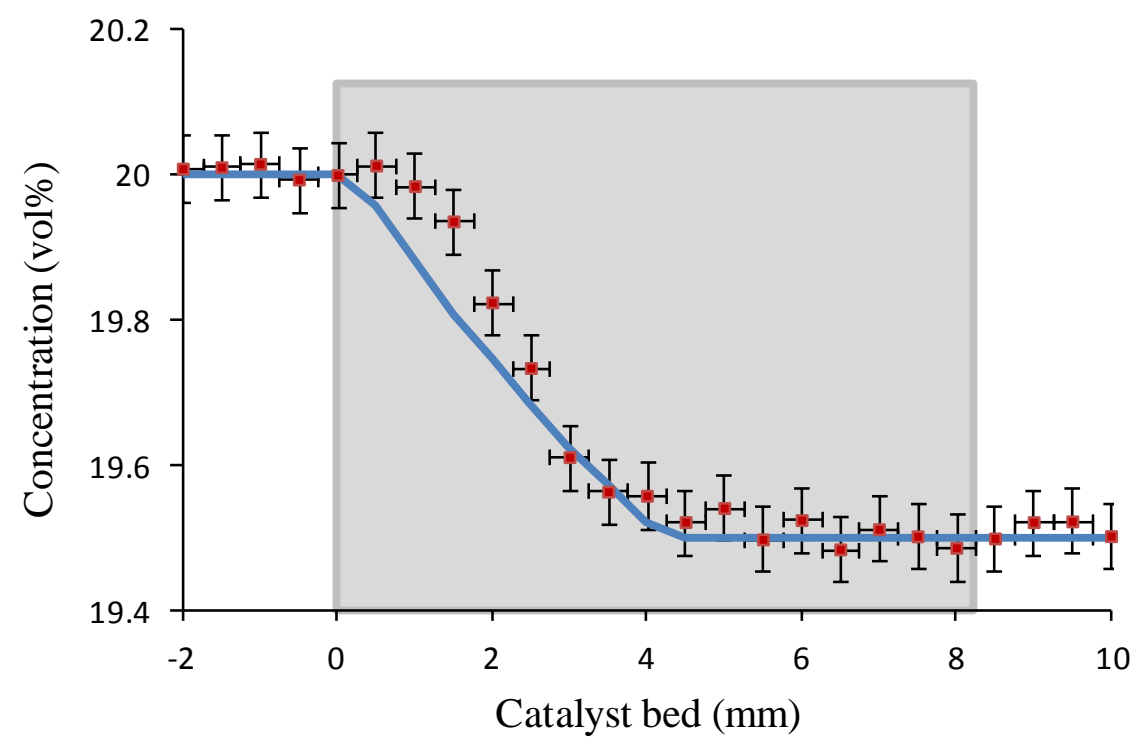

Figure S5 reports the $\mathrm{O}_{2}$ evolution at $175{ }^{\circ} \mathrm{C}$ with $1 \% \mathrm{CO}$ in the feed. The average accuracy was found to be 1.00 , giving an average error of $0.1 \%$. The $R^{2}$ value was 0.95 , meaning that the error on a point by point basis was $4.7 \%$, while the critical error was $4.8 \%$. 
Figure S6: $\mathrm{CO}_{2}$ experimental (square) and fully simulated model (line) evolution with $1 \%$ $\mathrm{CO}$ in the feed at $175^{\circ} \mathrm{C}$. The catalyst bed is represented by the shaded area.

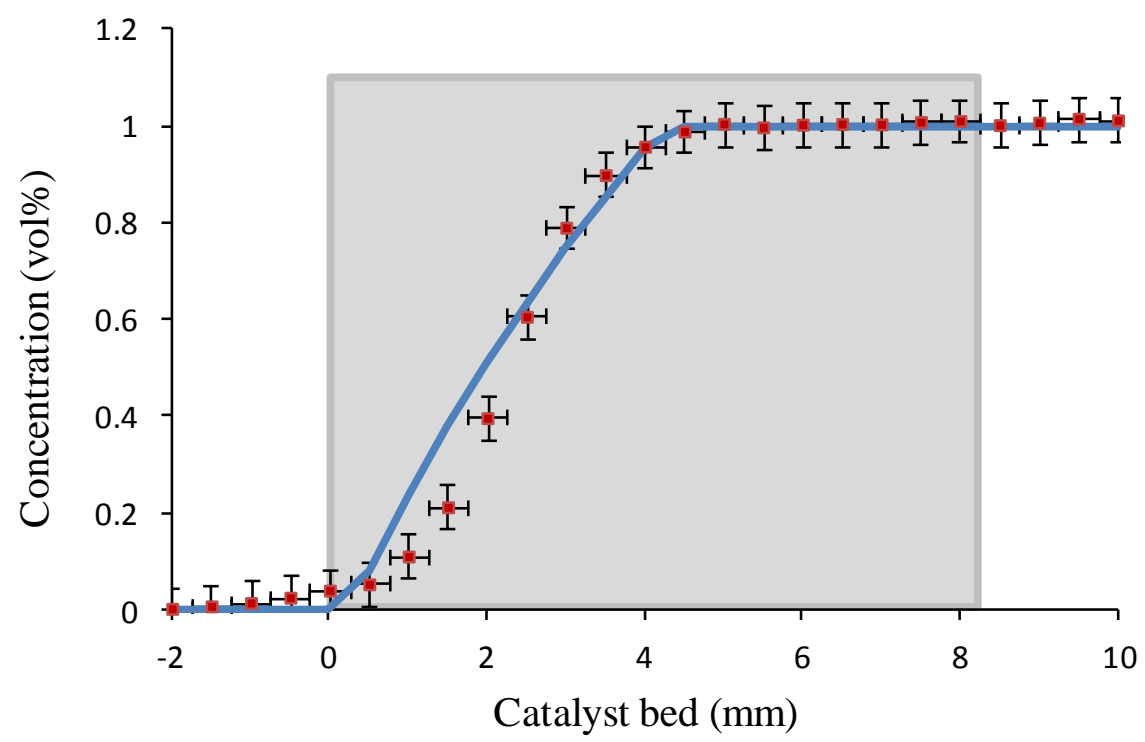

For Figure S6 the average accuracy was found to be 1.00, giving an average error of $0.0 \%$. The $R^{2}$ value was 0.98 meaning that the error on a point by point basis was $2.5 \%$, while the critical error was $2.5 \%$. 


\section{CO oxidation with $2 \% \mathrm{CO}$ at $175{ }^{\circ} \mathrm{C}$}

Figure S7: CO experimental (square) and fully simulated model (line) evolution with $2 \%$ $\mathrm{CO}$ in the feed at $175^{\circ} \mathrm{C}$. The catalyst bed is represented by the shaded area.

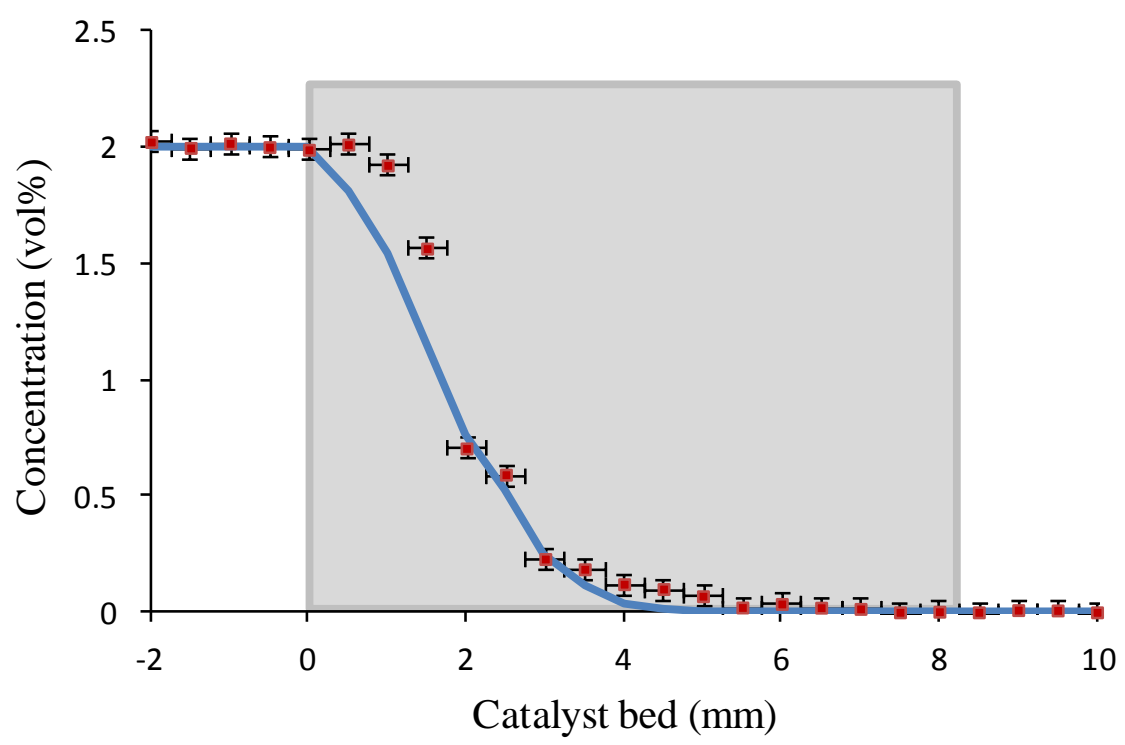

For Figure S7 the average accuracy was found to be 0.91 , giving an average error of $9.5 \%$. The $R^{2}$ value was 0.98 , meaning that the error on a point by point basis was $2.1 \%$, while the critical error was $11.4 \%$. 
Figure S8: $\mathrm{O}_{2}$ experimental (square) and fully simulated model (line) evolution with $2 \% \mathrm{CO}$ in the feed at $175^{\circ} \mathrm{C}$. The catalyst bed is represented by the shaded area.

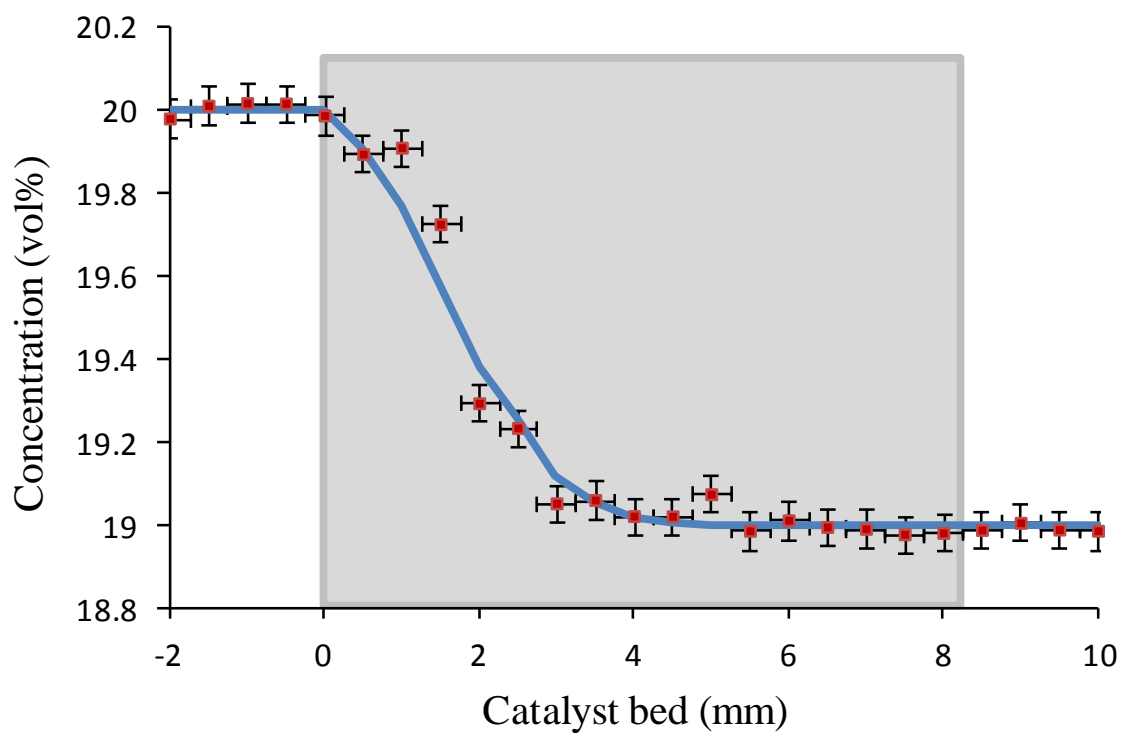

For Figure S8 the average accuracy was found to be 1.00, giving an average error of $0.1 \%$. The $R^{2}$ value was 0.98 , meaning that the error on a point by point basis was $2.3 \%$, while the critical error was $2.4 \%$. 
Figure S9: $\mathrm{CO}_{2}$ experimental (square) and fully simulated model (line) evolution with $2 \%$ $\mathrm{CO}$ in the feed at $175^{\circ} \mathrm{C}$. The catalyst bed is represented by the shaded area.

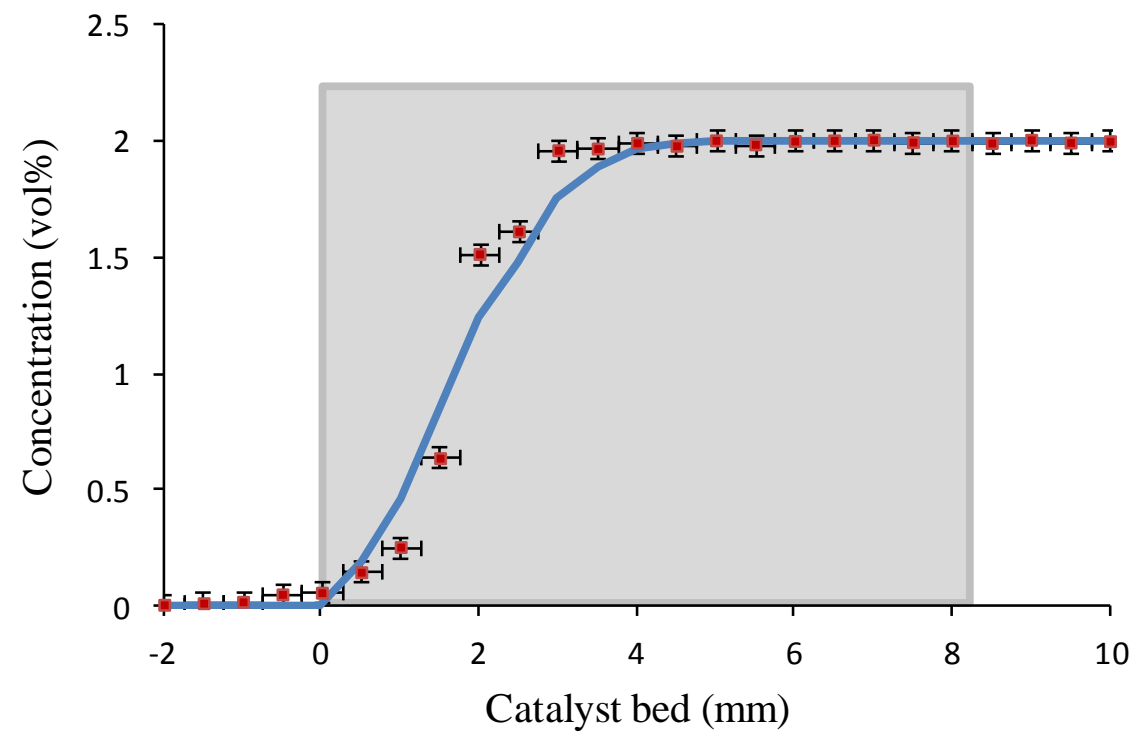

For Figure S9 the average accuracy was found to be 0.98 , giving an average error of $2.1 \%$. The $R^{2}$ value was 0.98 , meaning that the error on a point by point basis was $2.1 \%$, while the critical error was $4.1 \%$. 


\section{CO oxidation with $1 \% \mathrm{CO}$ at $175^{\circ} \mathrm{C}$}

Figure S10: CO experimental (square) and fully simulated model (line) evolution with $1 \%$ $\mathrm{CO}$ in the feed at $200{ }^{\circ} \mathrm{C}$. The catalyst bed is represented by the shaded area.

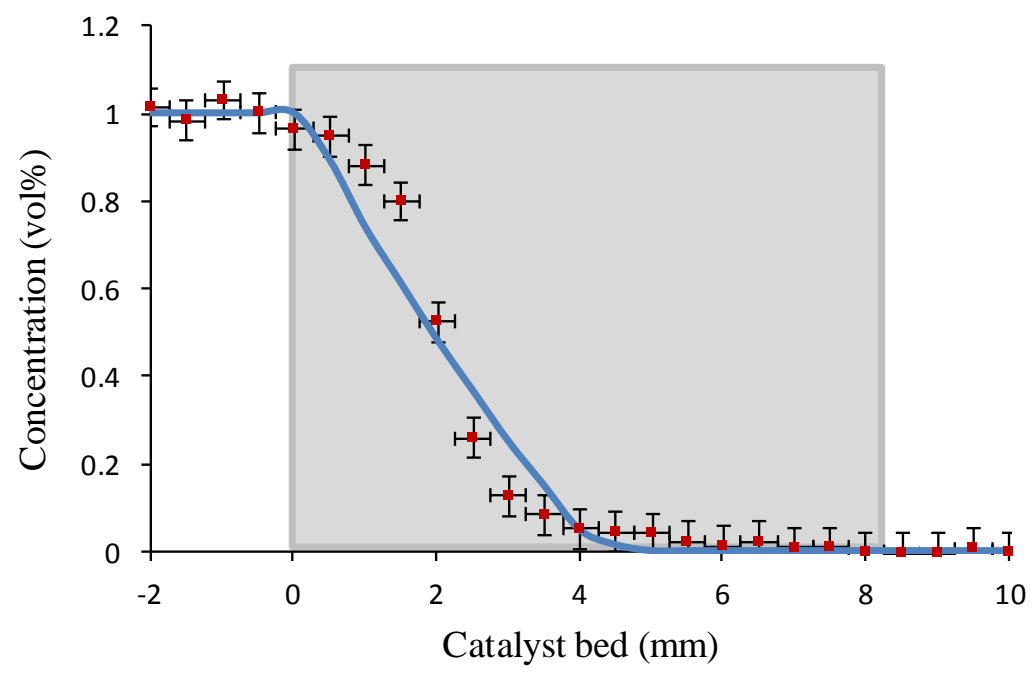

For Figure S10 the average accuracy was found to be 0.94 giving an average error of $6.3 \%$. The $R^{2}$ value was 0.97 , meaning that the error on a point by point basis was $3.1 \%$, while the critical error was $9.2 \%$. All of the experimental points matched the simulation within the experimental error with the exception of four points located in the catalyst bed $(1.5,2,3$ and $3.5 \mathrm{~mm})$. 
Figure S11: $\mathrm{O}_{2}$ experimental (square) and fully simulated model (line) evolution with $1 \%$ $\mathrm{CO}$ in the feed at $200{ }^{\circ} \mathrm{C}$. The catalyst bed is represented by the shaded area.

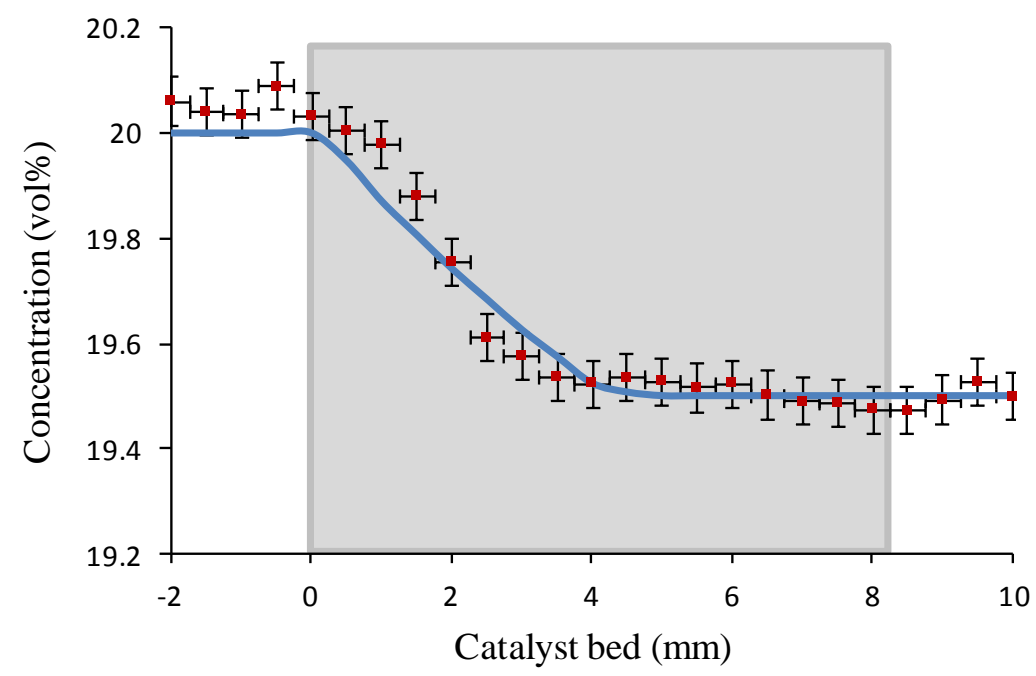

For Figure S11 the average accuracy was found to be 1.00, giving an average error of $0.1 \%$. The $R^{2}$ value was 0.94 , meaning that the error on a point by point basis was $6.2 \%$, while the critical error was $6.3 \%$. All of the experimental points matched the simulation within the experimental error with the exception of five points located before and in the catalyst bed ($2,-0.5,1,1.5$ and $2.5 \mathrm{~mm})$. 
Figure S12: $\mathrm{CO}_{2}$ experimental (square) and fully simulated model (line) evolution with $1 \%$ $\mathrm{CO}$ in the feed at $200{ }^{\circ} \mathrm{C}$. The catalyst bed is represented by the shaded area.

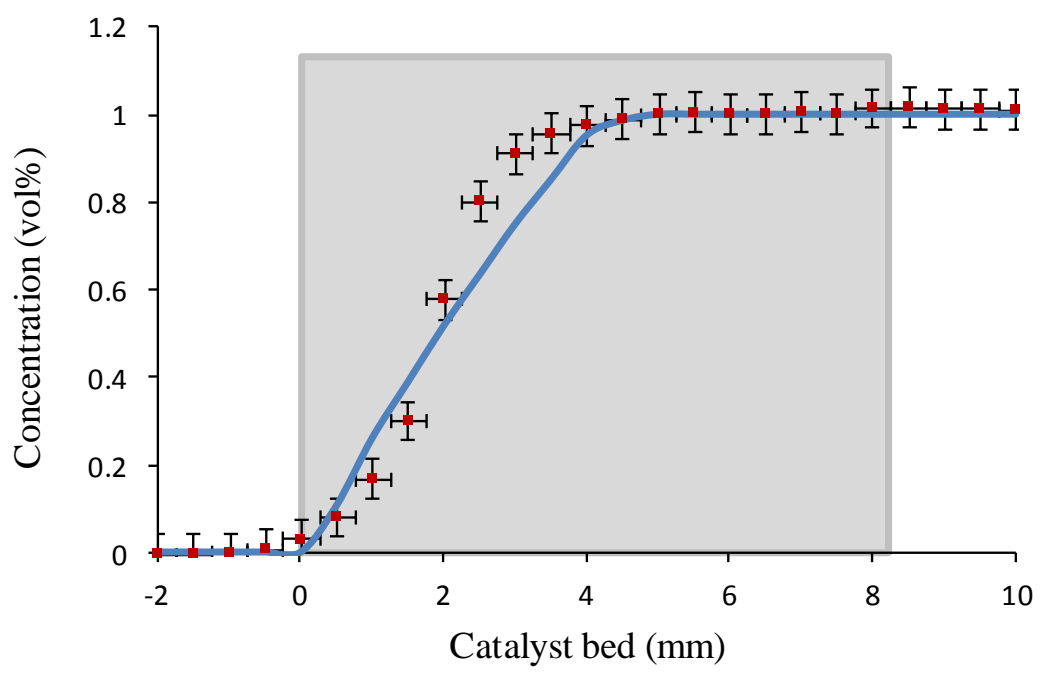

For Figure S12 the average accuracy was found to be 0.96, giving an average error of $3.7 \%$. The $R^{2}$ value was 0.97 , meaning that the error on a point by point basis was $2.9 \%$, while the critical error was $6.4 \%$. All of the experimental points matched the simulation within the experimental error with the exception of three points located in the catalyst bed $(2.5,3$ and $3.5 \mathrm{~mm})$. 


\section{CO oxidation with $2 \% \mathrm{CO}$ at $200{ }^{\circ} \mathrm{C}$}

Figure S13: CO experimental (square) and fully simulated model (line) evolution with $2 \%$ $\mathrm{CO}$ in the feed at $200{ }^{\circ} \mathrm{C}$. The catalyst bed is represented by the shaded area.

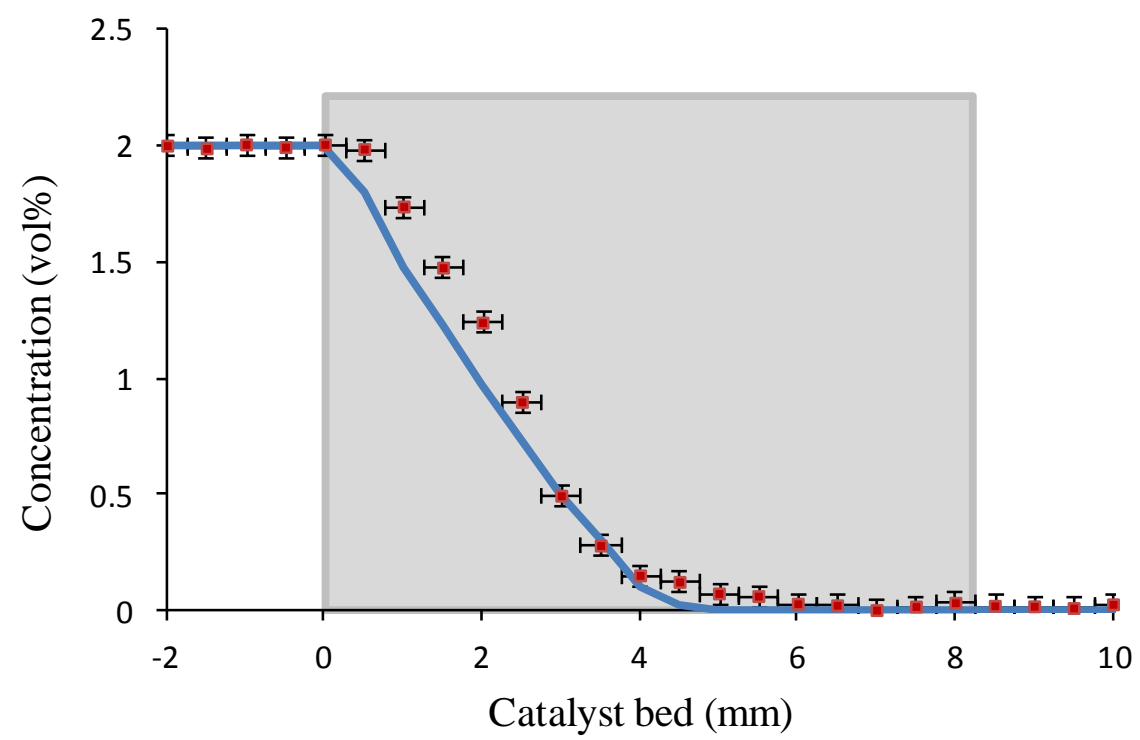

For Figure S13 the average accuracy was found to be 0.91 , giving an average error of $8.6 \%$. The $R^{2}$ value was 0.99 , meaning that the error on a point by point basis was $1.4 \%$, while the critical error was $9.9 \%$. 
Figure S14: $\mathrm{O}_{2}$ experimental (square) and fully simulated model (line) evolution with $2 \%$ $\mathrm{CO}$ in the feed at $200{ }^{\circ} \mathrm{C}$. The catalyst bed is represented by the shaded area.

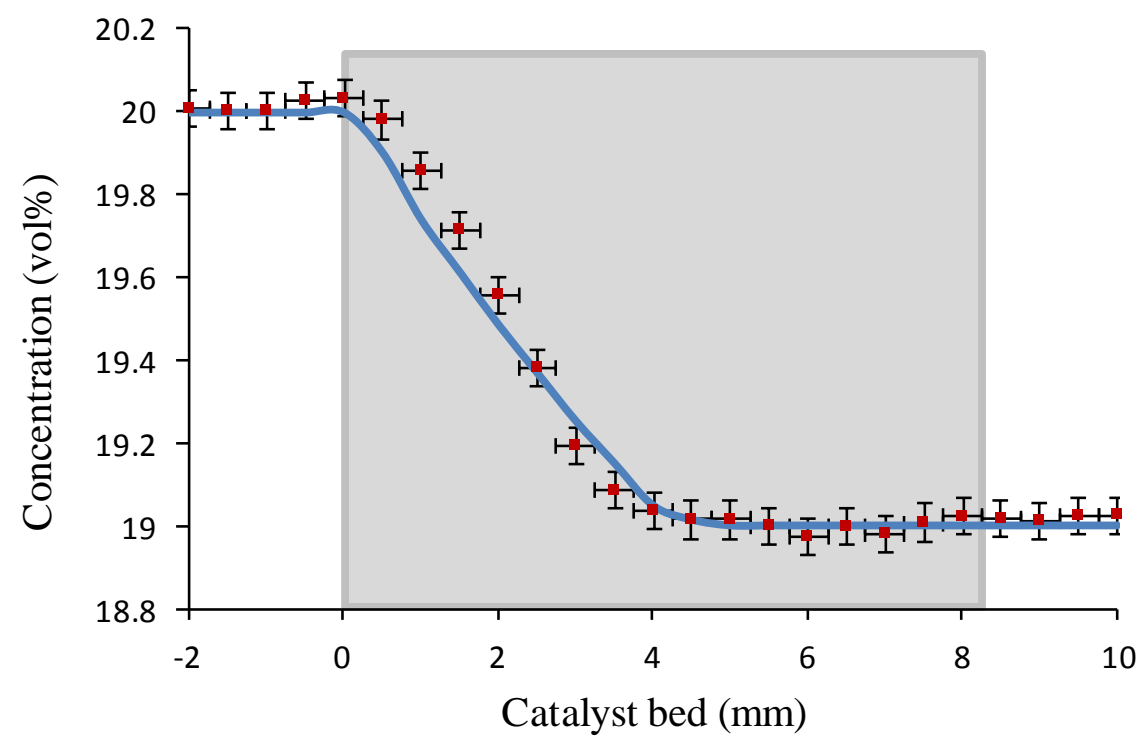

For Figure S14 the average accuracy was found to be 1.00, giving an average error of $0.1 \%$. The $R^{2}$ value was 0.98 , meaning that the error on a point by point basis was $1.6 \%$, while the critical error was $1.7 \%$. 
Figure S15: $\mathrm{CO}_{2}$ experimental (square) and fully simulated model (line) evolution with $2 \%$ $\mathrm{CO}$ in the feed at $200{ }^{\circ} \mathrm{C}$. The catalyst bed is represented by the shaded area.

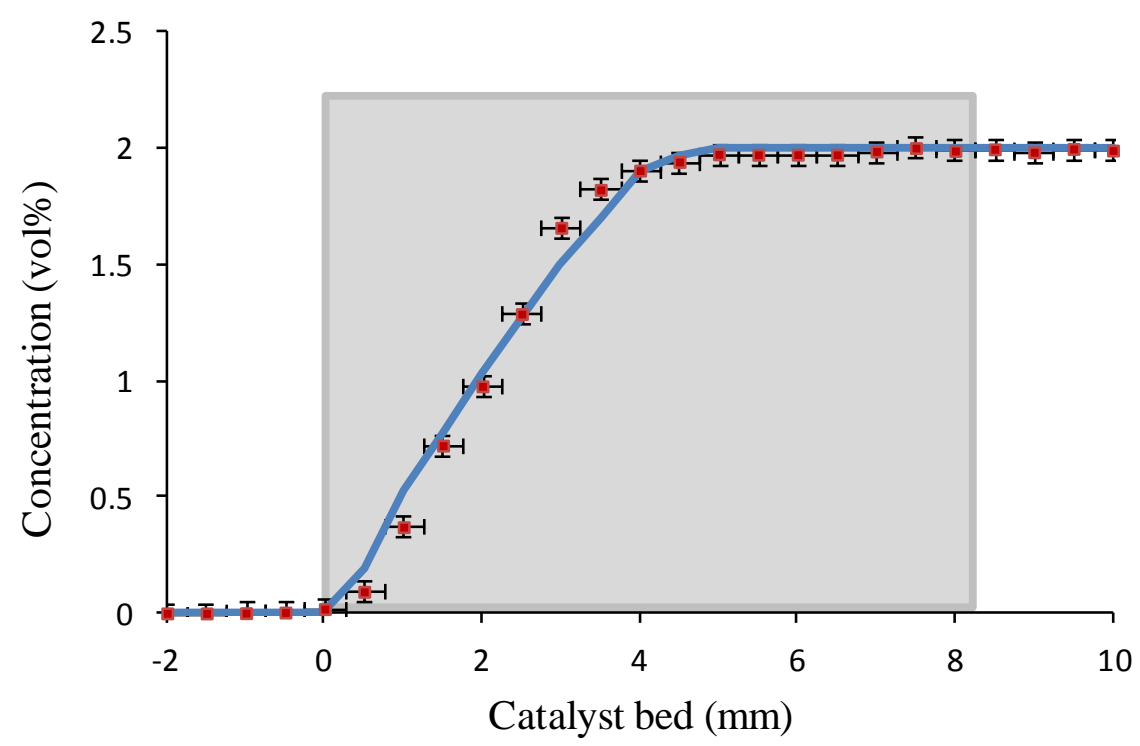

For Figure S15the average accuracy was found to be 1.00, giving an average error of $0.2 \%$. The $R^{2}$ value was 0.99 , meaning that the error on a point by point basis was $0.8 \%$, while the critical error was $1.0 \%$. 


\section{Comparison of experimental and simulated temperatures}

Figure S16: Evolution of the temperature in the catalyst bed, simulation (line) and experimental (square) with $1 \% \mathrm{CO}$ in the feed at $175{ }^{\circ} \mathrm{C}$. The catalyst bed is represented by the shaded area.

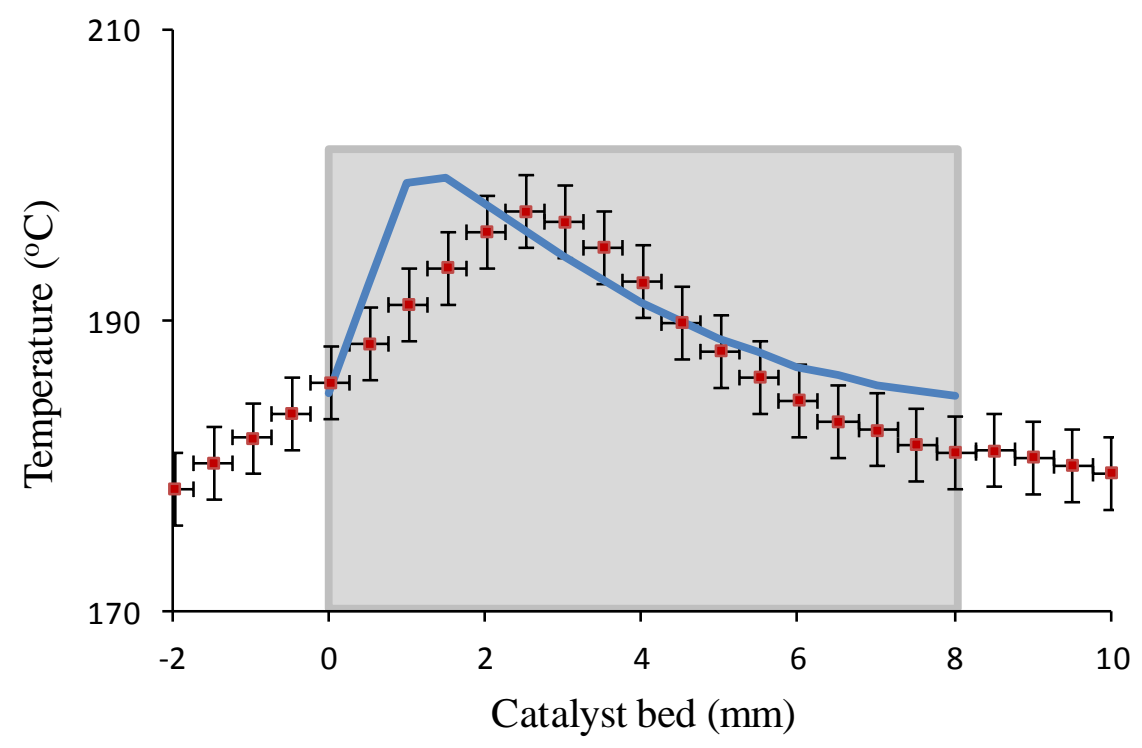

Figure S16 presents the evolution of the temperature in the catalyst bed with $1 \% \mathrm{CO}$ in the feed at $175^{\circ} \mathrm{C}$. A maximum difference is reached $1 \mathrm{~mm}$ into the bed with the experimental temperature value of $191.2{ }^{\circ} \mathrm{C}$ and the simulated temperature at the same point recorded as $199.5{ }^{\circ} \mathrm{C}$ a difference over $8{ }^{\circ} \mathrm{C}$ It then reached a hot spot maximum of $199.8{ }^{\circ} \mathrm{C}$ for the simulated data and $197.6^{\circ} \mathrm{C}$ for the experimental and the data did not match until $6 \mathrm{~mm}$, then the experimental results were more similar to the simulation. The general temperature profile is shifted by $1 \mathrm{~mm}$ as the hot spot of the experimental data occurred $1 \mathrm{~mm}$ after the simulated data. 
Figure S17: Evolution of the temperature in the catalyst bed, simulation (line) and experimental (square) with $2 \% \mathrm{CO}$ in the feed at $175{ }^{\circ} \mathrm{C}$. The catalyst bed is represented by the shaded area.

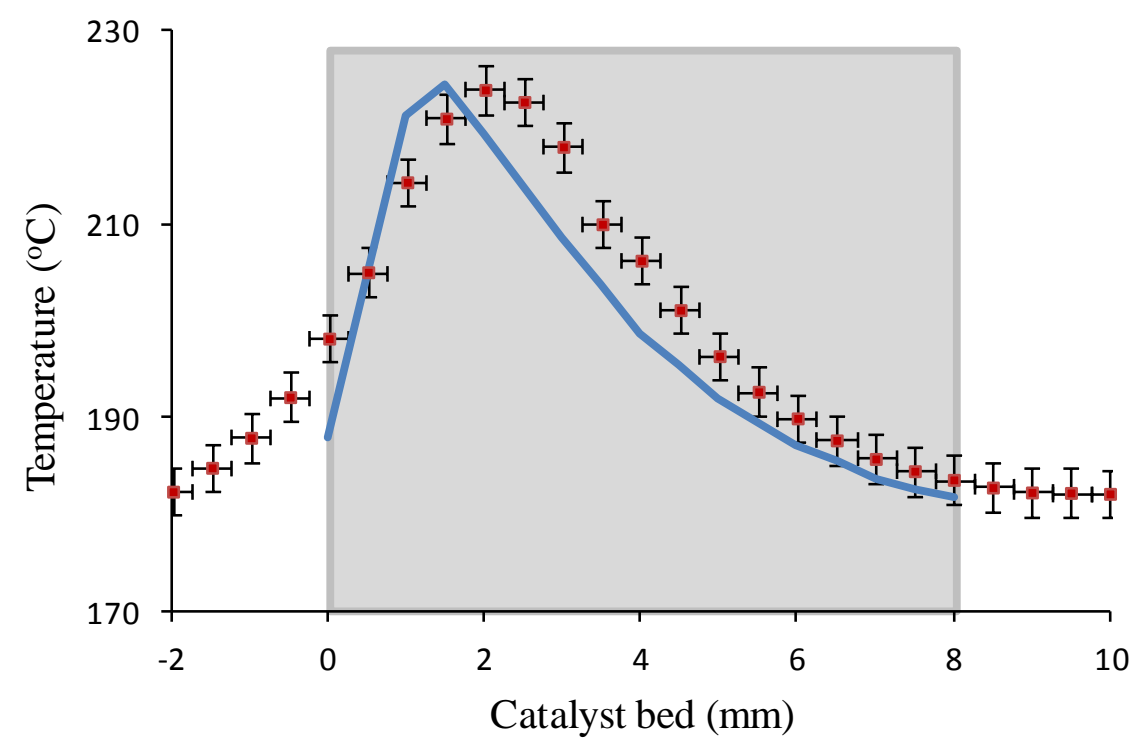

Figure S17 presents the evolution of the temperature in the catalyst bed with $2 \% \mathrm{CO}$ in the feed at $175{ }^{\circ} \mathrm{C}$. Both experimental and simulated data followed the general evolution. The correlation of the results at the beginning of the catalyst bed did not match as the temperature was $188{ }^{\circ} \mathrm{C}$ for the simulation and $198{ }^{\circ} \mathrm{C}$ for the experimental results. The increase of the temperature was faster for the simulation compared to the experimental results, with the hot spot maximum reached $224.3{ }^{\circ} \mathrm{C}$ at $1.5 \mathrm{~mm}$ in the catalyst bed for the simulation and then the temperature started to decrease. The evolution of profile of the experimental results presented the slowest increase of temperature and reached its hot spot of $224{ }^{\circ} \mathrm{C}$ at $2 \mathrm{~mm}$ in the catalyst bed then the temperature started to decrease. The data did not match but the differences were not too significant with the exception of the point at $1 \mathrm{~mm}$ in the catalyst bed. Similar to the previous graphs, the general temperature profile seems is shifted by $0.5 \mathrm{~mm}$ as the hot spot maximum of the experimental data occurred $0.5 \mathrm{~mm}$ after the simulated data. 
Figure S18: Evolution of the temperature in the catalyst bed, simulation (line) and experimental (square) with $2 \% \mathrm{CO}$ in the feed at $200{ }^{\circ} \mathrm{C}$. The catalyst bed is represented by the shaded area.

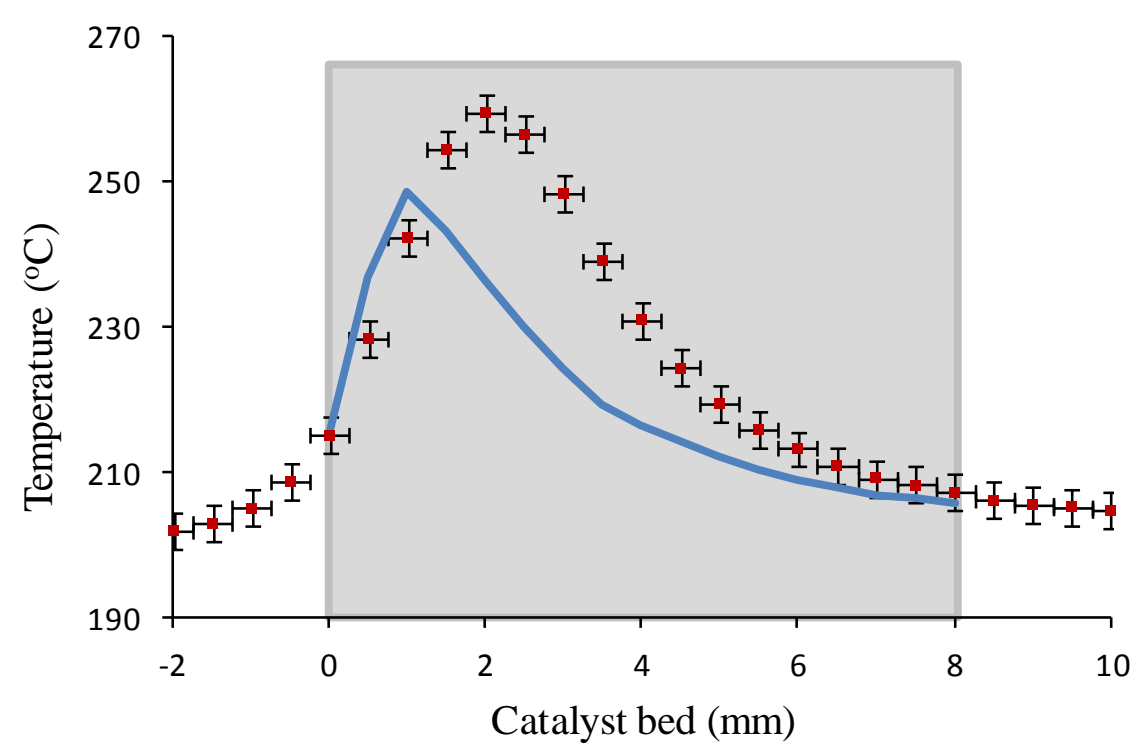

Figure S18 presents the evolution of the temperature in the catalyst bed with $2 \% \mathrm{CO}$ in the feed at $200{ }^{\circ} \mathrm{C}$. Both experimental and simulated data followed the general evolution. The correlation of the results at the beginning of the catalyst bed did match as the temperature was $215^{\circ} \mathrm{C}$ for the simulation and experimental results. As with the previous graph, the increase of the temperature was faster for the simulation compared to the experimental results, with the hot spot maximum of $248.7^{\circ} \mathrm{C}$ reached at $1 \mathrm{~mm}$ in the catalyst bed for the simulation and then the temperature started to decrease. The simulated and experimental temperatures were in agreement at the end of the experiment due to a faster decrease of the experimental temperature. Similar to the previous figures, the general temperature profile is shifted by 1 $\mathrm{mm}$ as the hot spot maximum of the experimental data occurred $1 \mathrm{~mm}$ after the simulated data. 
Comparison of gas concentration profiles from experimental with semi-empirical model

\section{CO oxidation with $1 \% \mathrm{CO}$ at $175^{\circ} \mathrm{C}$}

Figure S19: CO experimental (square) and semi-empirical model (line) evolution with $1 \%$ $\mathrm{CO}$ in the feed at $175^{\circ} \mathrm{C}$. The catalyst bed is represented by the shaded area.

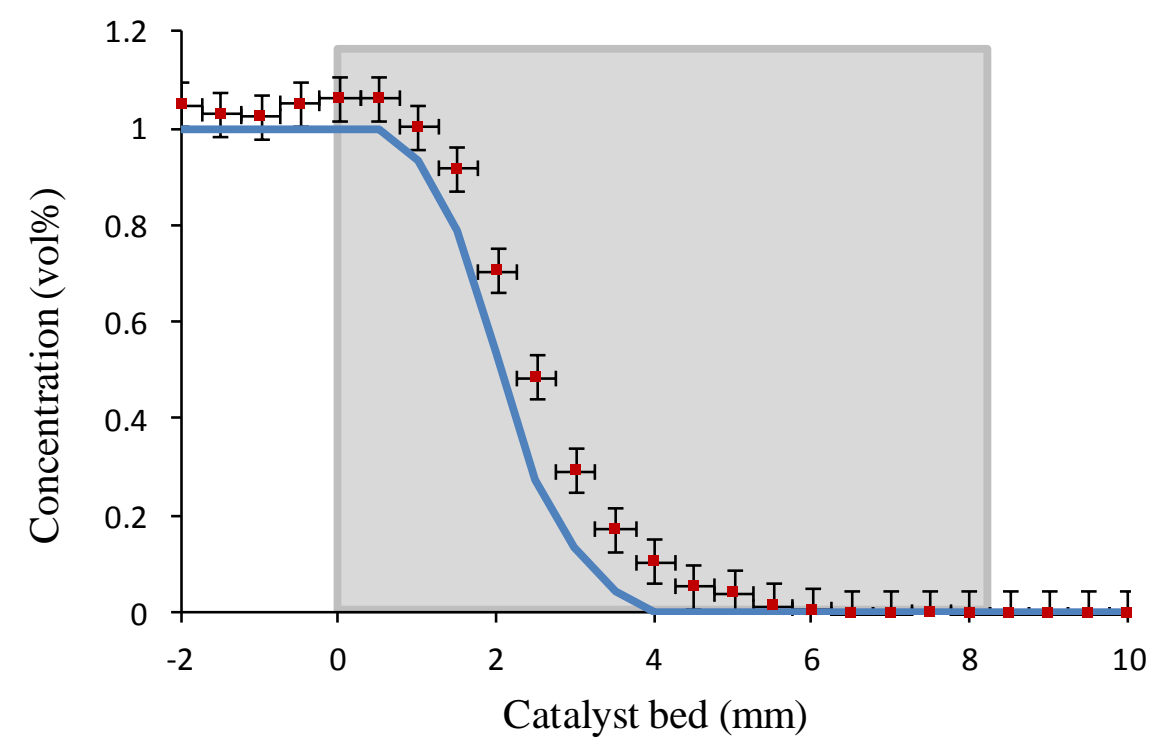

Figure S19 reports the $\mathrm{CO}$ evolution at $175{ }^{\circ} \mathrm{C}$ with $1 \% \mathrm{CO}$ in the feed. The average accuracy was found to be 0.89 , giving an average error of $11.3 \%$. The $R^{2}$ value was 0.97 , meaning that the error on a point by point basis was $2.8 \%$, while the critical error was 13.8 $\%$. 
Figure S20: $\mathrm{O}_{2}$ experimental (square) and semi-empirical model (line) evolution with $1 \%$ $\mathrm{CO}$ in the feed at $175^{\circ} \mathrm{C}$. The catalyst bed is represented by the shaded area.

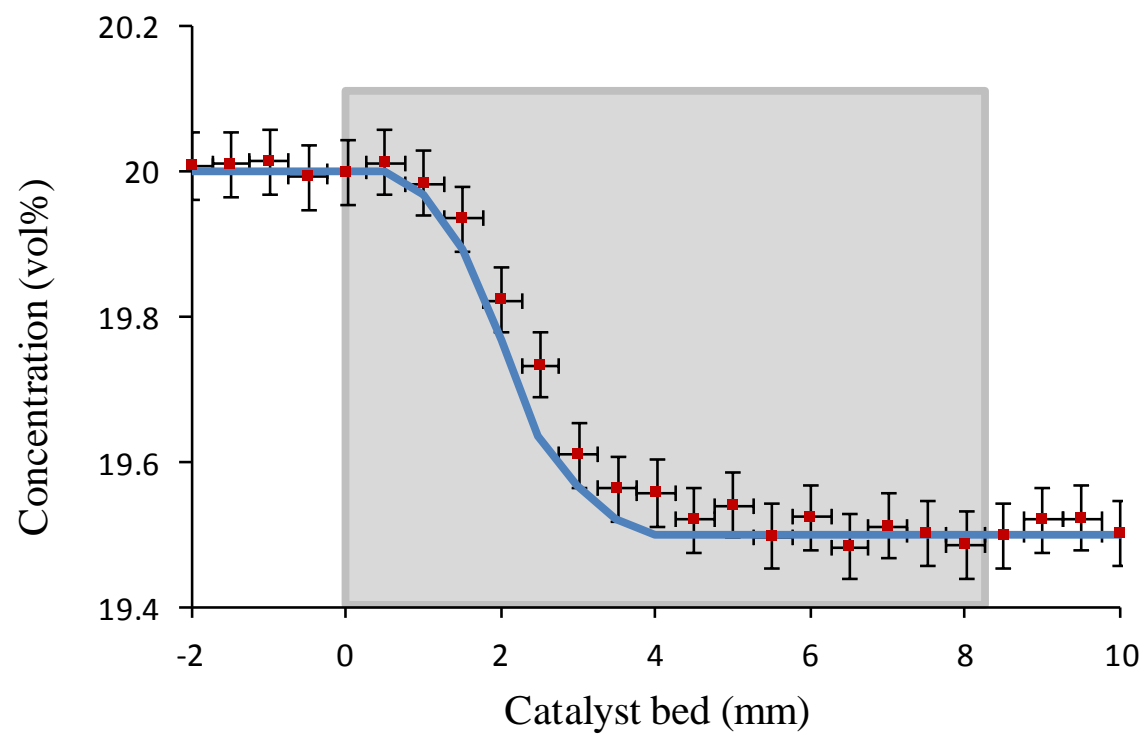

Figure S20 reports the $\mathrm{O}_{2}$ evolution at $175^{\circ} \mathrm{C}$ with $1 \% \mathrm{CO}$ in the feed. The average accuracy was found to be 1.00 , giving an average error of $0.1 \%$. The $R^{2}$ value was 0.98 , meaning that the error on a point by point basis was $2.0 \%$, while the critical error was $2.1 \%$. 
Figure S21: $\mathrm{CO}_{2}$ experimental (square) and semi-empirical model (line) evolution with $1 \%$ $\mathrm{CO}$ in the feed at $175^{\circ} \mathrm{C}$. The catalyst bed is represented by the shaded area.

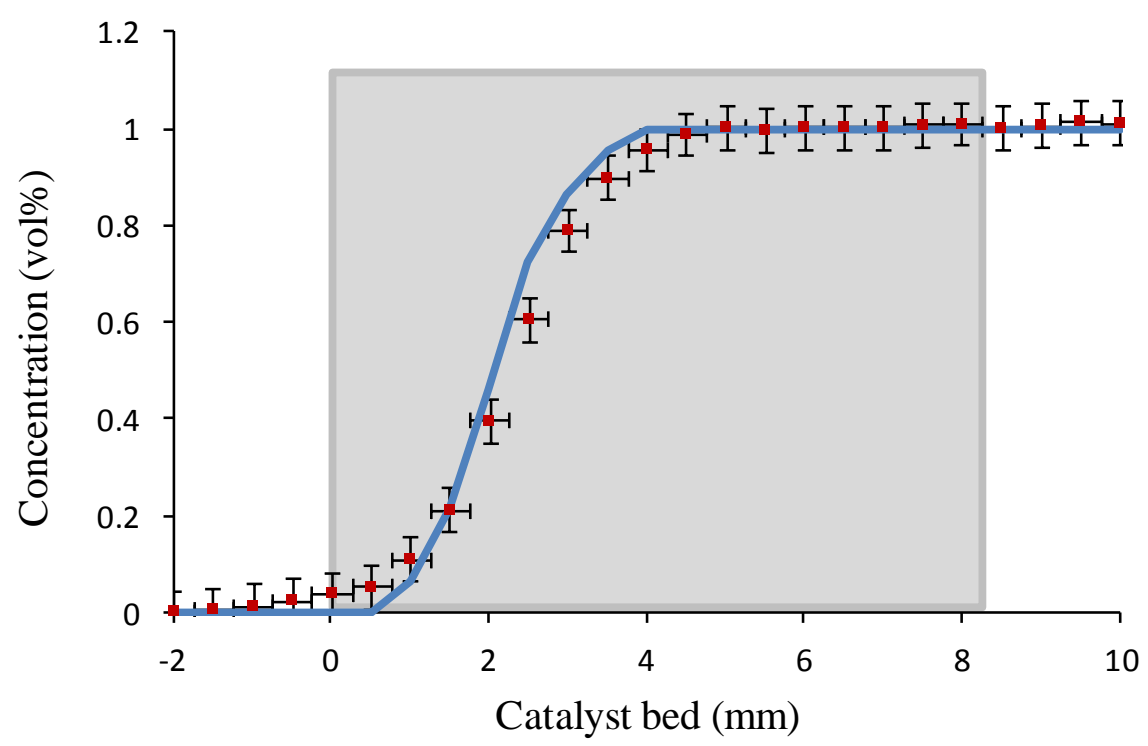

Figure S21 reports the $\mathrm{CO}_{2}$ evolution at $175{ }^{\circ} \mathrm{C}$ with $1 \% \mathrm{CO}$ in the feed. The average accuracy was found to be 1.02 , giving an average error of $1.7 \%$. The $R^{2}$ value was 0.99 , meaning that the error on a point by point basis was $1.1 \%$, while the critical error was $0.7 \%$. 


\section{CO oxidation with $2 \% \mathrm{CO}$ at $175^{\circ} \mathrm{C}$}

Figure S22: CO experimental (square) and semi-empirical model (line) evolution with $2 \%$ $\mathrm{CO}$ in the feed at $175^{\circ} \mathrm{C}$. The catalyst bed is represented by the shaded area.

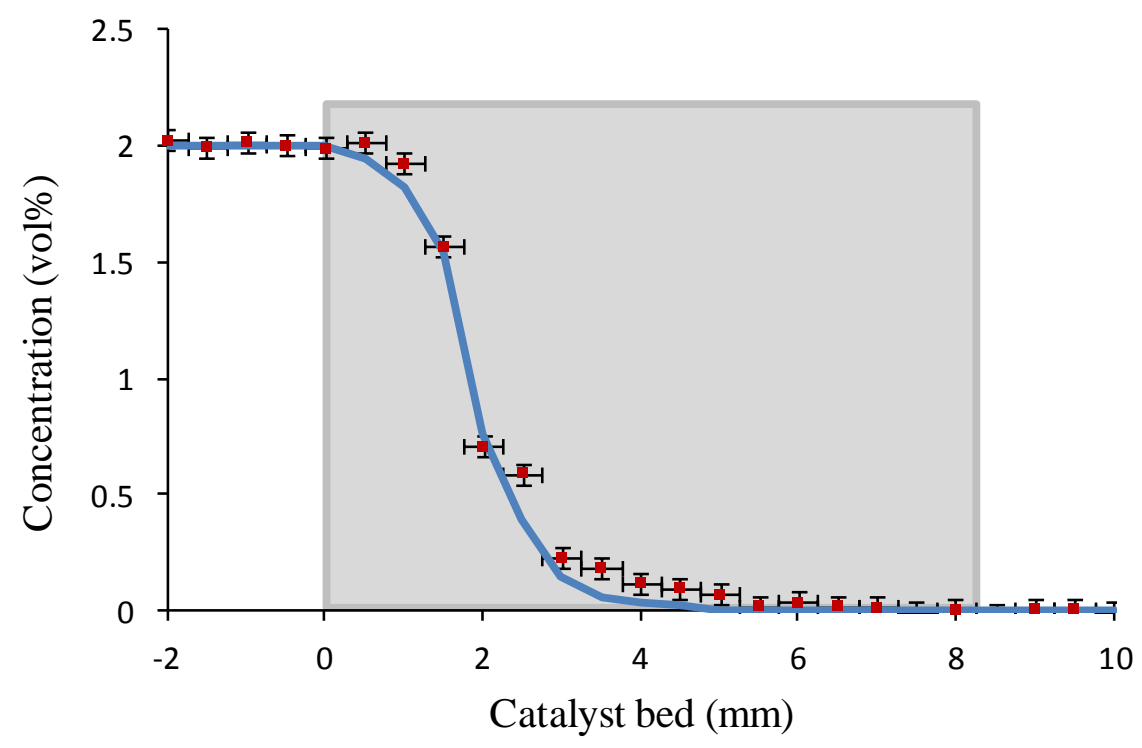

Figure S22 reports the $\mathrm{CO}$ evolution at $175{ }^{\circ} \mathrm{C}$ with $2 \% \mathrm{CO}$ in the feed. The average accuracy was found to be 0.97 , giving an average error of $2.6 \%$. The $\mathrm{R}^{2}$ value was 0.99 , meaning that the error on a point by point basis was $0.7 \%$, while the critical error was $3.3 \%$. 
Figure S23: $\mathrm{O}_{2}$ experimental (square) and semi-empirical model (line) evolution with $2 \%$ $\mathrm{CO}$ in the feed at $175^{\circ} \mathrm{C}$. The catalyst bed is represented by the shaded area.

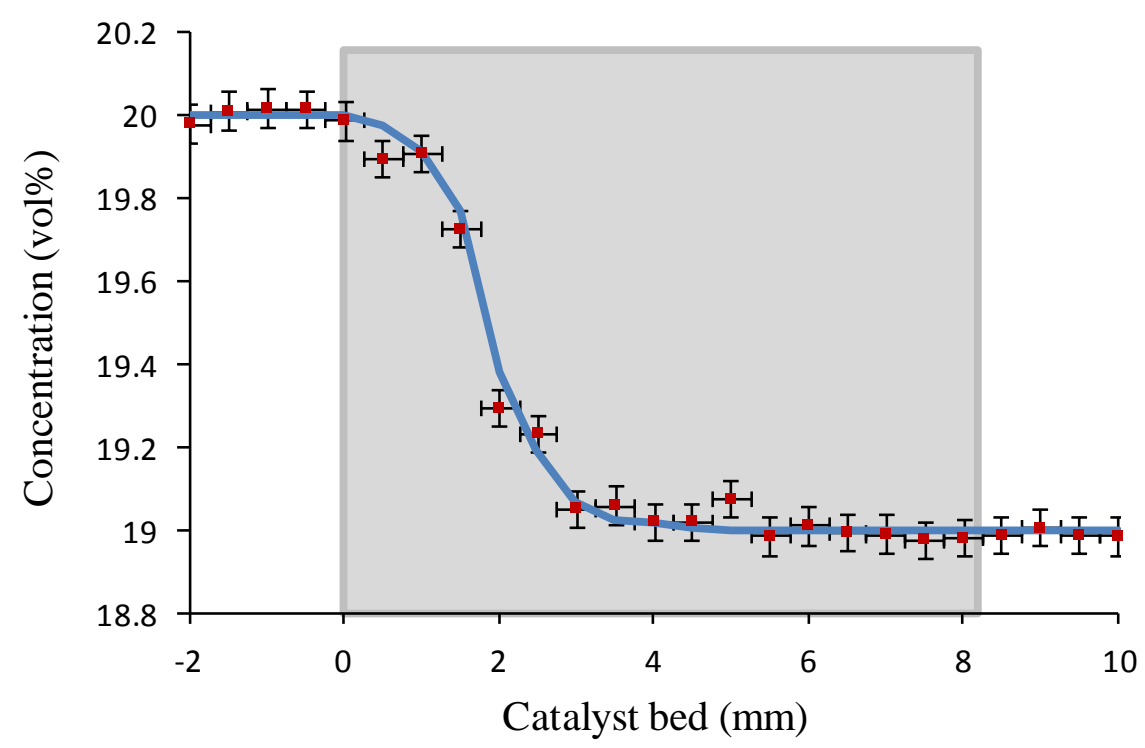

Figure S23 reports the $\mathrm{O}_{2}$ evolution at $175^{\circ} \mathrm{C}$ with $2 \% \mathrm{CO}$ in the feed. The average accuracy was found to be 1.00 , giving an average error of $0.0 \%$. The $\mathrm{R}^{2}$ value was 0.99 , meaning that the error on a point by point basis was $0.8 \%$, while the critical error was $0.8 \%$. 
Figure S24: $\mathrm{CO}_{2}$ experimental (square) and semi-empirical model (line) evolution with $2 \%$ $\mathrm{CO}$ in the feed at $175^{\circ} \mathrm{C}$. The catalyst bed is represented by the shaded area.

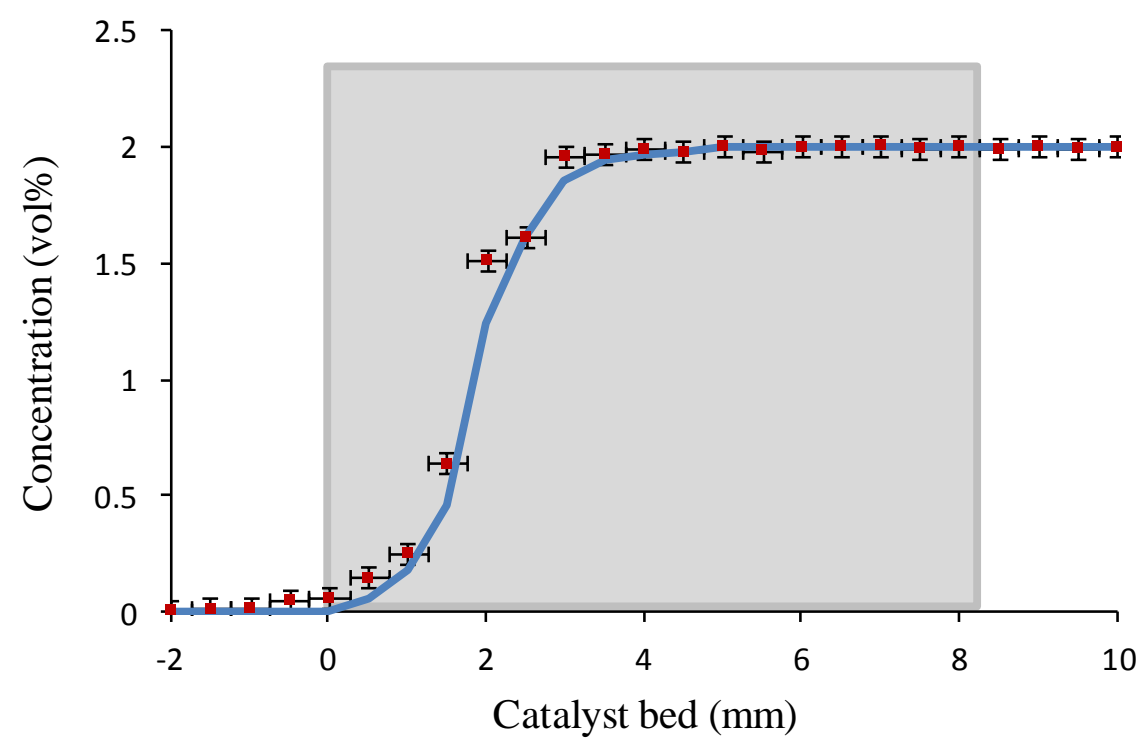

Figure S24 reports the $\mathrm{CO}_{2}$ evolution at $175{ }^{\circ} \mathrm{C}$ with $2 \% \mathrm{CO}$ in the feed. The average accuracy was found to be 0.98 , giving an average error of $1.8 \%$. The $\mathrm{R}^{2}$ value was 0.99 , meaning that the error on a point by point basis was $1.1 \%$, while the critical error was $2.8 \%$. 


\section{CO oxidation with $1 \% \mathrm{CO}$ at $200{ }^{\circ} \mathrm{C}$}

Figure S25: CO experimental (square) and semi-empirical model (line) evolution with $1 \%$ $\mathrm{CO}$ in the feed at $200{ }^{\circ} \mathrm{C}$. The catalyst bed is represented by the shaded area.

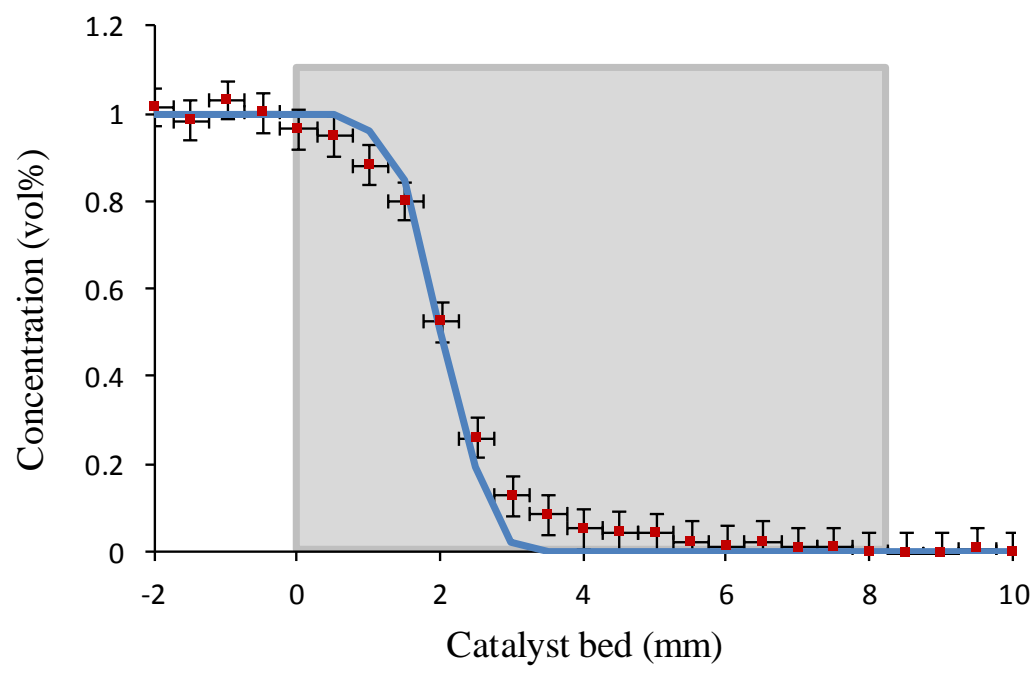

Figure $\mathrm{S} 25$ shows the $\mathrm{CO}$ evolution at $200{ }^{\circ} \mathrm{C}$ with $1 \% \mathrm{CO}$ in the feed. The average accuracy was found to be 1.03 , giving an average error of $2.6 \%$. The $R^{2}$ value was 0.99 , meaning that the error on a point by point basis was $1.3 \%$, while the critical error was $1.2 \%$. All of points matched the simulation within the experimental error with the exception of two points located in the catalyst bed ( 3 and $3.5 \mathrm{~mm})$. 
Figure S26: $\mathrm{O}_{2}$ experimental (square) and semi-empirical model (line) evolution with $1 \%$ $\mathrm{CO}$ in the feed at $200{ }^{\circ} \mathrm{C}$. The catalyst bed is represented by the shaded area.

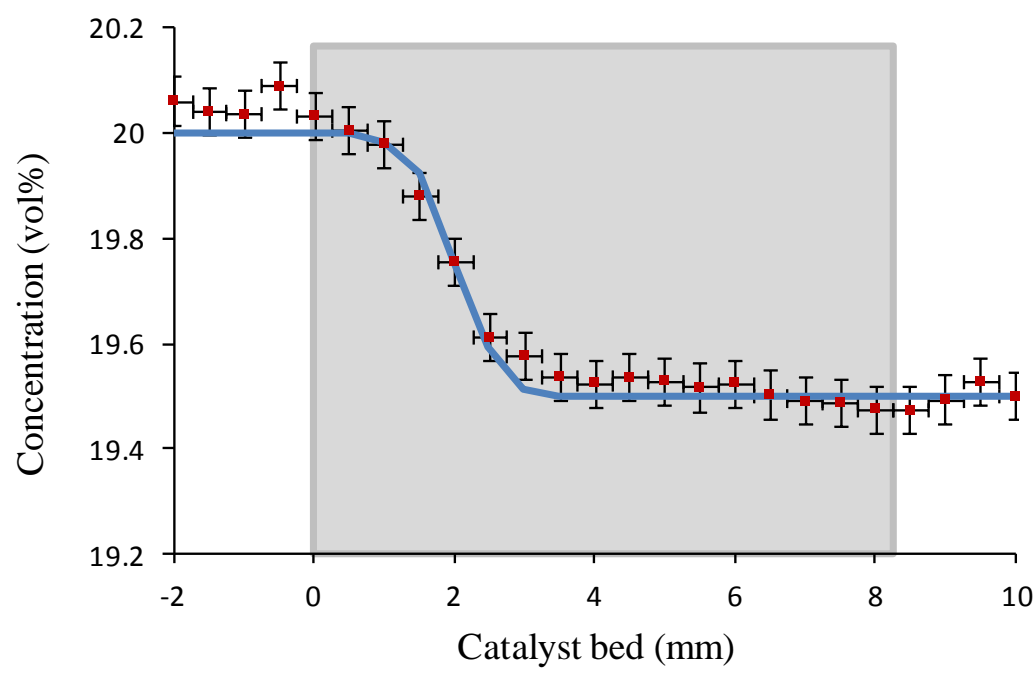

Figure S26 shows the $\mathrm{O}_{2}$ evolution at $200{ }^{\circ} \mathrm{C}$ with $1 \% \mathrm{CO}$ in the feed. The average accuracy was found to be 1.00 , giving an average error of $0.1 \%$. The $R^{2}$ value was 0.98 , meaning that the error on a point by point basis was $2.2 \%$, while the critical error was $2.3 \%$. All of the points matched the simulation within the experimental error with the exception of two points located before the catalyst bed ( -2 and $-0.5 \mathrm{~mm})$. 
Figure S27: $\mathrm{CO}_{2}$ experimental (square) and semi-empirical model (line) evolution with $1 \%$ $\mathrm{CO}$ in the feed at $200{ }^{\circ} \mathrm{C}$. The catalyst bed is represented by the shaded area.

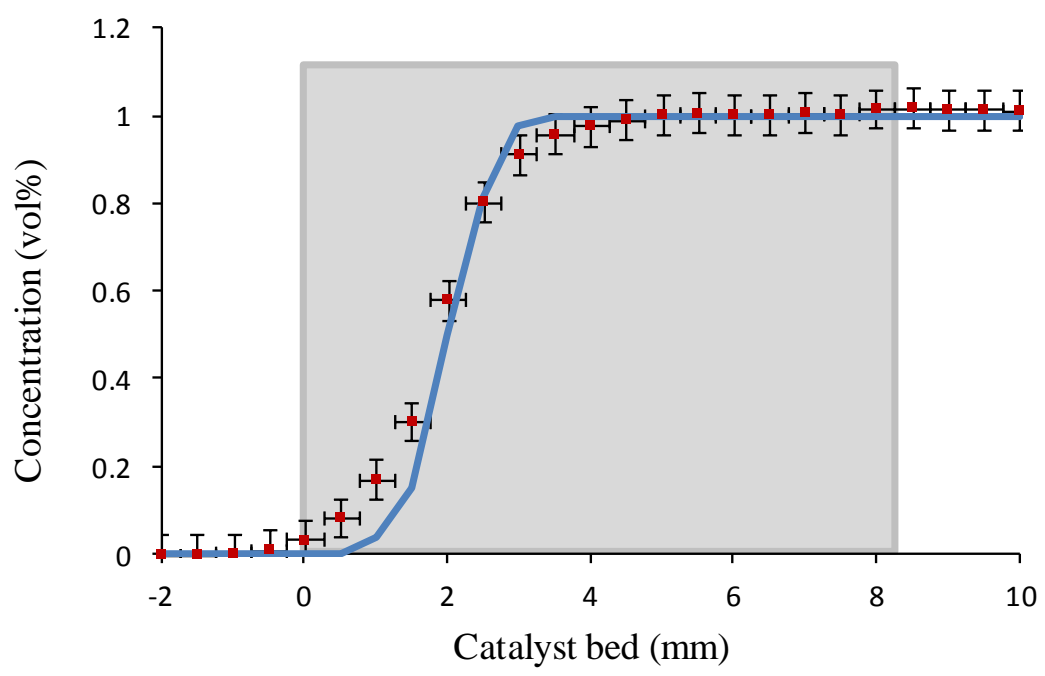

Figure $\mathrm{S} 27$ shows $\mathrm{CO}_{2}$ evolution at $200{ }^{\circ} \mathrm{C}$ with $1 \% \mathrm{CO}$ in the feed. The average accuracy was found to be 1.00 , giving an average error of $0.4 \%$. The $R^{2}$ value was 0.98 , meaning that the error on a point by point basis was $1.9 \%$, while the critical error was $2.3 \%$. All of the points matched the simulation within the experimental error with the exception of two points located in the catalyst bed $(0.5$ and $1 \mathrm{~mm})$. 


\section{CO oxidation with $2 \% \mathrm{CO}$ at $200{ }^{\circ} \mathrm{C}$}

Figure S28: CO experimental (square) and semi-empirical model (line) evolution with $2 \%$ $\mathrm{CO}$ in the feed at $200{ }^{\circ} \mathrm{C}$. The catalyst bed is represented by the shaded area.

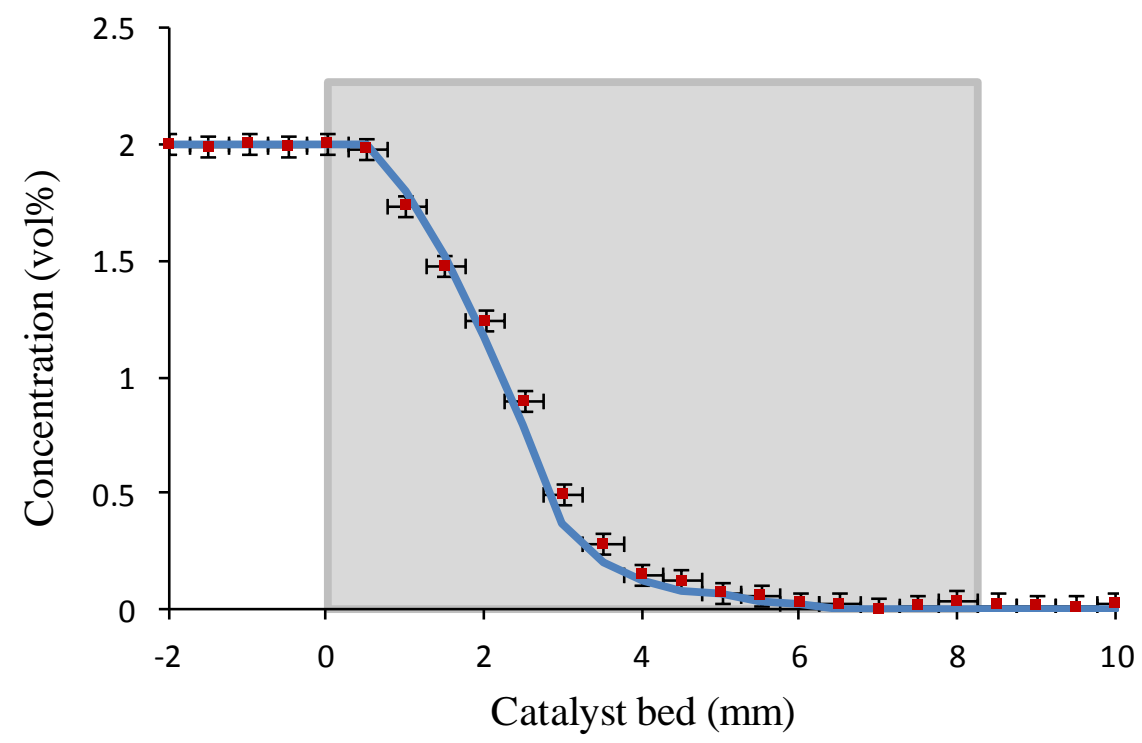

Figure S28 reports the $\mathrm{CO}$ evolution at $200{ }^{\circ} \mathrm{C}$ with $2 \% \mathrm{CO}$ in the feed. The average accuracy was found to be 1.00 , giving an average error of $0.5 \%$. The $R^{2}$ value was 1.00 , meaning that the error on a point by point basis was $0.4 \%$, while the critical error was $0.9 \%$. 
Figure S29: $\mathrm{O}_{2}$ experimental (square) and semi-empirical model (line) evolution with $2 \%$ $\mathrm{CO}$ in the feed at $200{ }^{\circ} \mathrm{C}$. The catalyst bed is represented by the shaded area.

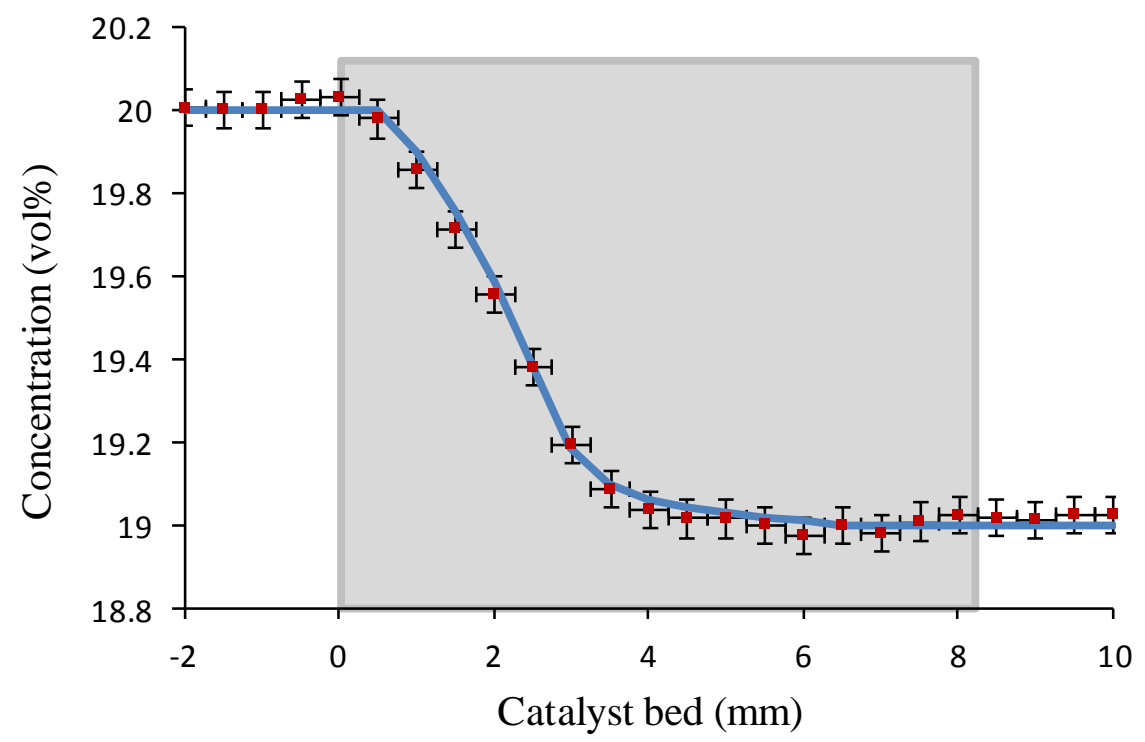

Figure S29 reports the $\mathrm{O}_{2}$ evolution at $200{ }^{\circ} \mathrm{C}$ with $2 \% \mathrm{CO}$ in the feed. The average accuracy was found to be 1.000 , giving an average error of $0.0 \%$. The $R^{2}$ value was 1.00 , meaning that the error on a point by point basis was $0.3 \%$, while the critical error was $0.3 \%$. 
Figure S30: $\mathrm{CO}_{2}$ experimental (square) and semi-empirical model (line) evolution with $2 \%$ $\mathrm{CO}$ in the feed at $200{ }^{\circ} \mathrm{C}$. The catalyst bed is represented by the shaded area.

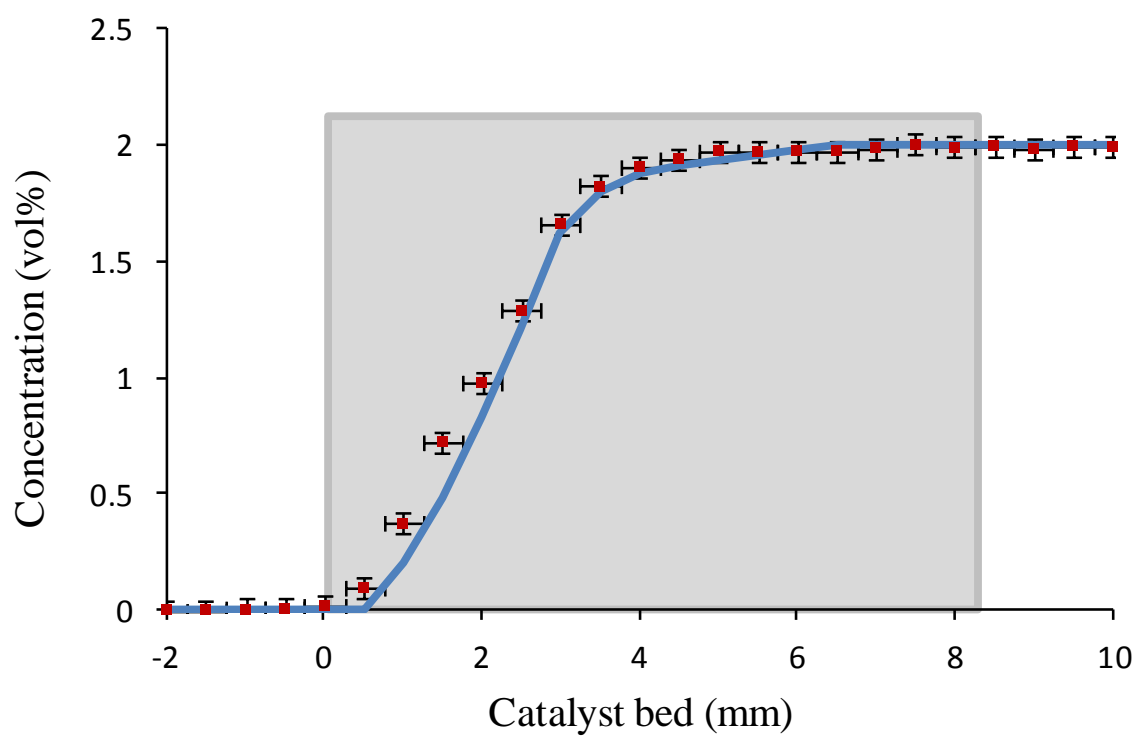

Figure S30 reports the $\mathrm{CO}_{2}$ evolution at $200{ }^{\circ} \mathrm{C}$ with $2 \% \mathrm{CO}$ in the feed. The average accuracy was found to be 0.99 , giving an average error of $1.1 \%$. The $R^{2}$ value was 0.99 , meaning that the error on a point by point basis was $1.0 \%$, while the critical error was $2.1 \%$. 


\section{Notation}

$A$ pre-exponential $\left(\mathrm{mol} \mathrm{cm} \mathrm{cm}^{-2} \mathrm{~s}^{-1}\right)$

$A_{D}$ desorption pre-exponential $\left(\mathrm{s}^{-1}\right)$

$A_{S}$ surface reaction pre-exponential $\left(\mathrm{s}^{-1}\right)$

$C_{C v}$ concentration of active sites $\left(\mathrm{mol} \mathrm{m}^{-3}\right)$

$C_{D}, i$ desorption surface concentration $\left(\mathrm{mol} \mathrm{m}^{-3}\right)$

$C_{g}, i$ gas concentration $\left(\mathrm{mol} \mathrm{m}{ }^{-3}\right)$

$C_{p}, i$ pseudo-surface concentration $\left(\mathrm{mol} \mathrm{mol}^{-1}\right)$

$C_{s}, i$ surface concentration $\left(\mathrm{mol} \mathrm{mol}^{-1}\right)$

$C_{v}$ factor of free sites (-)

$E_{a}$ activation energy $\left(\mathrm{kJ} \mathrm{mol}^{-1}\right)$

$k$ rate constant $\left(\mathrm{mol} \mathrm{cm} \mathrm{cm}^{-2} \mathrm{~s}^{-1}\right.$

$k_{A}$ absorption rate constant $\left(\mathrm{m}^{3} \mathrm{~mol}^{-1} \mathrm{~s}^{-1}\right)$

$k_{D}$ desorption rate constant $\left(\mathrm{s}^{-1}\right)$

$k_{S}$ surface rate constant $\left(\mathrm{s}^{-1}\right)$

$k_{a i}$ inhibition parameters $\left(\mathrm{mol} \mathrm{cm} \mathrm{c}^{-1} \mathrm{~s}^{-1}\right)$

$M_{i}$ molecular mass $\left(\mathrm{kg} \mathrm{mol}^{-1}\right)$

$r$ reaction rate $\left(\mathrm{mol} \mathrm{cm} \mathrm{cm}^{-2}\right)$

$r_{A}$ reaction rate of adsorption $\left(\mathrm{mol} \mathrm{s}^{-1}\right)$

$r_{D}$ reaction rate of desorption $\left(\mathrm{mol} \mathrm{s}^{-1}\right)$

$r_{S}$ surface reaction rate $\left(\mathrm{mol} \mathrm{s}^{-1}\right)$

$R$ universal gas constant $\left(\mathrm{J} \mathrm{mol}^{-1} \mathrm{~K}^{-1}\right)$

$R(\theta)$ inhibition term (-)

$S_{0 i}$ sticking coefficient (-)

$T$ gas temperature $(\mathrm{K})$

$T_{0}$ reference temperature $(\mathrm{K})$

$b$ temperature exponent (-)

\section{References}

(1) Stewart, J., Douglas, R., Goguet, A., Glover L. SAE Technical Paper 2012 (2012-011638)

(2) Stewart, J., Douglas, R., Goguet, A., Proc. IMechE Part D: J Automobile Engineering 2014, 228, $285-2294$. 